\title{
Potential Conservation Opportunities from the Use of Improved Irrigation Scheduling in the Pacific Northwest Region
}

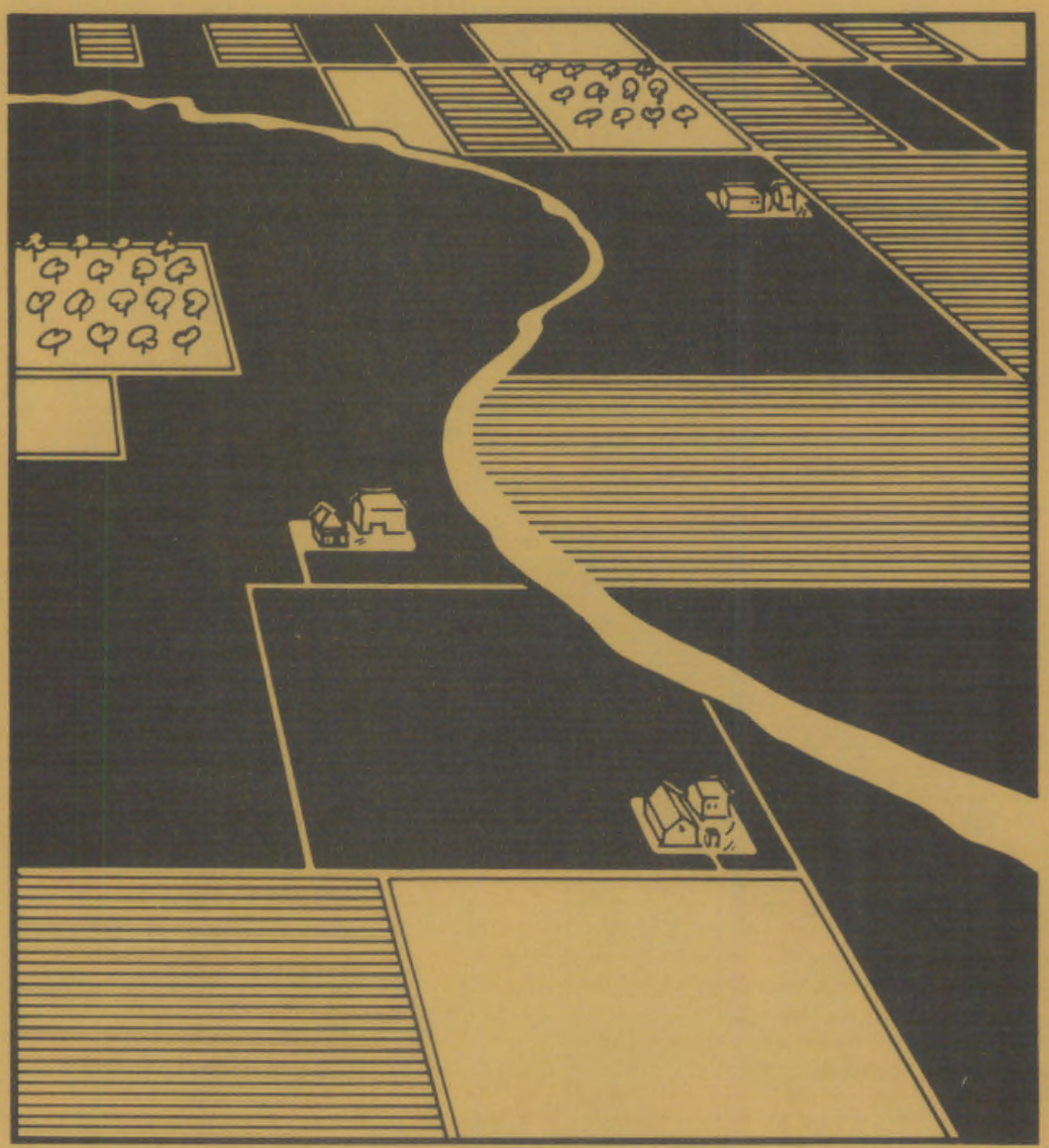

March 1985

Prepared for the Bonneville Power Administration Office of Conservation Planning under a Related Services Agreement with the U.S. Department of Energy under Contract DE-AC06-76RLO 1830

Pacific Northwest Laboratory Operated for the U.S. Department of Energy by Battelie Memorial Institute 


\title{
DISCLAIMER
}

This report was prepared as an account of work sponsored by an agency of the United States Government. Neither the United States Government nor any agency thereof, nor any of their employees, makes any warranty, express or implied, or assumes any legal liability or responsibility for the accuracy, completeness, or usefulness of any information, apparatus, product, or process disciosed, or represents that its use would not infringe privately owned rights. Reference herein to any specific commercial product, process, or service by trade name, trademark, manufacturer, or otherwise, does not necessarily constitute or imply its endorsement, recommendation, or favoring by the United States Government or any agency thereof. The views and opinions of authors expressed herein do not necessarily state or reflect those of the United States Government or any agency thereof.

\author{
PACIFIC NORTHWEST LABORATORY \\ operated by \\ BATTELLE \\ for the \\ UNITED STATES DEPARTMENT OF ENERGY \\ under Contract DE-AC06-76RLO 1830
}

\begin{tabular}{|c|c|}
\hline \multicolumn{2}{|c|}{ Printed in the United States of America } \\
\hline \multicolumn{2}{|c|}{ Available from } \\
\hline \multirow{4}{*}{\multicolumn{2}{|c|}{$\begin{array}{c}\text { National Technical Information Service } \\
\text { United States Department of Commerce } \\
5285 \text { Port Royal Road } \\
\text { Springfield, Virginia } 22161\end{array}$}} \\
\hline & \\
\hline & \\
\hline & \\
\hline \\
\hline \multicolumn{2}{|c|}{ Microfiche $A 01$} \\
\hline \multicolumn{2}{|c|}{ Printed Copy } \\
\hline & Price \\
\hline Pages & Codes \\
\hline $001-025$ & A02 \\
\hline $026-050$ & $\mathrm{~A} 03$ \\
\hline $051-075$ & AO4 \\
\hline $076-100$ & A05 \\
\hline $101-125$ & AOS \\
\hline $126-150$ & A07 \\
\hline $151-175$ & A06 \\
\hline $176-200$ & $\mathrm{~A} 09$ \\
\hline $201-225$ & A010 \\
\hline $226-250$ & A011 \\
\hline $251-275$ & $\mathrm{~A} 012$ \\
\hline $276-300$ & $A 013$ \\
\hline
\end{tabular}


PNL -5416

UC $-95 \mathrm{C}$

POTENTIAL CONSERVATION

OPPORTUNITIES FROM

THE USE OF IMPROVED IRRIGATION

SCHEDULING IN THE PACIFIC

NORTHWEST REGIDN

B. J. Harrer

A. J. Lezberg

March 1985

Prepared for

the Bonneville Power Administration Office of Conservation Planning under a Related Services Agreement with the U.S. Department of Energy under Contract DE-ACO6-76RLO 1830

Pacific Northwest Laboratory

Richland, Washington 99352 


\section{SUMMARY}

This report documents research to identify the potential energy savings and the costs per kWh saved from using systematic rather than traditional irrigation scheduling to reduce water usage in the irrigated agricultural sector of the Pacific Northwest. This research is part of an overali project aimed at developing a computer model and data base that will allow for estimation of the potential energy savings and cost effectiveness of a number of conservation technologies that are available for use in irrigated agriculture. The project is being sponsored by the Bonneville Power Administration (BPA), Division of Conservation Planning, and is intended to aid BPA in its overall conservation planning efforts.

A computer model, known as ISEP (Irrigation Sector Energy Planning), that simulates the energy consumption process of irrigation systems and estimates the levelized costs of undertaking conservation improvements has been developed by Pacific Northwest Laboratory personnel. ISEP is the primary analytical tool utilized in this study. The model generates energy savings and cost per kWh saved estimates using engineering and economic input parameters for the various conservation measures that could be implemented in irrigated agriculture. The objective of this report is to provide documentation on the input parameters that were provided to the model and the output results that were generated for improved irrigation scheduling.

Only "full" scheduling services, where a per-acre charge is assessed for continuous soil moisture monitoring and evapotranspiration analysis, were analyzed in this study. It is believed that such services, which are usually provided by qualified irrigation scheduling consultants, will be the most effective means of facilitating more efficient water usage in irrigation.

Although more field research is needed on the effectiveness of improved scheduling in the Pacific Northwest, it is conservatively estimated that the use of such scheduling rather than traditional irrigation scheduling can reduce farm-level water and energy use by an average of over 20 percent on fields irrigated with center-pivot sprinkler irrigation systems and over 10 percent on fields irrigated with other types of sprinkler systems. Improved scheduling was not found to be effective in reducing water and energy use on gravity flow 
systems. A representative per-acre charge for improved scheduling is approximately six dollars, and cost-sharing arrangements between BPA and irrigators could reduce the costs per acre to both parties.

Various potential technical limits were examined with regard to their impact upon the feasibility of using improved irrigation scheduling in specific irrigation situations. Limiting factors that were studied included the periodic delivery of water in surface water supply systems, under capacity of groundwater wells, and the lack of control over water application anounts for gravity flow systems. Based on this analysis, it was concluded that there is no sound justification for placing any broad technical limits on the application of improved scheduling to sprinkler irrigated acres, although such limits may apply in a limited number of specific situations. Acres irrigated with gravity flow irrigation systems were excluded from the analysis of systematic scheduling because of the lack of control of water application amounts that is normally associated with these systems.

Improved scheduling is already being used by a small number of Pacific Northwest irrigators. The use of improved scheduling seems to be most widespread on acres irrigated with center pivots, on water-sensitive crops, and in the major irrigation subregions of the Columbia Basin in Washington, northcentral Oregon, and southern Idaho. All of these factors were incorporated in developing estimates of 124,000 acres for center-pivot systems and 200,000 acres for non-center-pivot sprinkler systems to represent the number of acres on which improved scheduling has already been implemented. These acres were subtracted from baseline acres in developing energy savings estimates for improved irrigation scheduling.

It is likely that systematic scheduling will be adopted more rapidly on water-sensitive crops than on non-water-sensitive crops because improved irrigation scheduling on water-sensitive crops can improve crop yields, in addition to reducing water and energy use. To account for this, all estimation of the costs and energy-savings potential of systematic irrigation scheduling was divided into water-sensitive and non-water-sensitive crops. Watersensitive crops included potatoes, corn, and other miscellaneous crops, while 
non-water-sensitive crops were specified as wheat, hay, orchard, and several other miscellaneous crops.

It was assumed in this study that low-pressure irrigation and efficient fitting and mainline design had been implemented on all sprinkler irrigation systems prior to the use of improved irrigation scheduling. Thus, all of the energy savings estimates calculated for improved scheduling are based on an application head of 90 feet at the pivot for center-pivot systems and 95 feet at the source point for non-center-pivot sprinkler systems.

Under the generally conservative assumptions used in this study, the study results show that approximately 22.2 average MW can be saved by using improved scheduling on existing center-pivot acres at an average cost of approximately 21 mills per kWh saved on groundwater acres and 57 mills on acres irrigated with surface water. On existing other sprinkler acres, approximately $25.8 \mathrm{MW}$ can be saved at an average cost of approximately 48 mills per kWh saved when ground water is used and approximately 126 mills when surface water is used. Estimated potential energy savings on new acres were relatively small at $7.6 \mathrm{MW}$ for all types of sprinkler-irrigated acres by the year 2003. The estimated average costs of obtaining these savings were generally higher than for existing acres because the majority of the new acres that are forecast to be developed in the next 20 years are expected to be irrigated with surface water.

The large disparity in cost per kWh saved between groundwater and surface water installations is directly related to the larger average pumping lifts of groundwater irrigation. The use of improved scheduling on surface water installations with large pumping lifts would be equally as cost effective as for groundwater installations. The large differences in cost per $\mathrm{kWh}$ saved between center-pivot and other sprinkler acres is attributable to lower assumed effectiveness for improved scheduling on other sprinkler acres.

Although the costs per $\mathrm{kWh}$ saved estimates for improved scheduling appear to be relatively high, a substantial proportion of the energy savings from improved scheduling can be obtained for much lower costs if the scheduling programs are selectively targeted to particular irrigation situations and cost sharing arrangements with irrigators are used. For example, over 70 percent of the total potential energy savings on existing center-pivot acres could be obtained for a cost of $30 \mathrm{mills}$ per $\mathrm{kWh}$ saved or less, if BPA's share of the cost of the scheduling program was six dollars per acre. In addition, the 
total potential energy savings estimates developed in this study may significantly understate the full energy savings benefits of improved irrigation scheduling, because the indirect energy savings associated with reducing water withdrawals from the regional hydroelectric system were not incorporated in the analysis. 


\section{CONCLUSIONS AND RECOMMENOATIONS}

The energy-savings potential and costs per kWh of savings for improved irrigation scheduling are evaluated in this study for a cost per acre charged for scheduling services of six dollars. A summary of the results of the analysis of improved irrigation scheduling on water-sensitive crop acres ${ }^{1}$ is presented in Summary Table 1. The percentage water savings estimates for improved scheduling, from which the energy savings estimates presented in Sumary Table 1 were calculated, ranged from 11 percent on potato acres irrigated with other sprinkler systems to 22 percent on corn irrigated with center pivots. Compared to many field test results on the effectiveness of systematic scheduling, these water savings estimates are conservative. In particular, the percentage water savings for improved scheduling on other sprinkler systems were evaluated in an extremely conservative manner. Thus, the energy savings estimates shown in Summary Tables 1 and 2 should be conservatively low, and the cost per kWh saved estimates should be conservatively high.

The results of the analysis of improved irrigation scheduling on non-watersensitive crop acres ${ }^{2}$ are summarized in Sumary Table 2. The estimated energy-savings potential on non-water-sensitive crop acres is significantly higher than the estimated potential on water-sensitive crop acres because of the larger number of non-water-sensitive crop acres. On a per-acre basis, the energy savings on non-water-sensitive crops will generally be slightly lower than for water-sensitive crops, because water application volumes are generally lower on non-water-sensitive crops.

The numbers presented in Summary Tables 1 and 2 are based solely on the direct energy savings that could occur at the farm level from improved irrigation scheduling. Estimates of the indirect energy savings that could

1 For purposes of this study, water-sensitive crop acres are defined as potatoes, corn and other miscellaneous crops.

2 For purposes of this study, non-water-sensitive crop acres are defined as wheat, hay, orchard and other miscellaneous crops. 
SUMMARY TABLE 1. Cost per kWh Saved and Energy-Savings Potential for Improved Irrigation Scheduling on Water-Sensitive Crops

\begin{tabular}{|c|c|c|c|c|c|}
\hline \multirow[b]{2}{*}{$\begin{array}{l}\text { Improved } \\
\text { Scheduling Alternat ive }\end{array}$} & \multicolumn{3}{|c|}{ Cost per kWh Saved (1984 mills ) } & \multicolumn{2}{|c|}{ Energy Savings Potential (MW) } \\
\hline & $\begin{array}{l}\text { Average } \\
\text { Swlaj }\end{array}$ & $\begin{array}{l}\text { Average } \\
\text { GW }\end{array}$ & $\operatorname{Range}^{(c)}$ & $\begin{array}{c}\text { All } \\
\text { Applications (d) }\end{array}$ & $\begin{array}{l}30 \mathrm{Mil}(\mathrm{s}) \\
\text { or Less }\end{array}$ \\
\hline $\begin{array}{l}\text { Existing Center-Pivot } \\
\text { Acres at } \$ 6 \text { per Acre }\end{array}$ & 58.4 & 20.6 & $14.3-149.5$ & 6.7 & 5.2 \\
\hline $\begin{array}{l}\text { Existing 0ther Sprinkler } \\
\text { Acres at } \$ 6 \text { per Acre }\end{array}$ & 133.9 & 47.9 & $23.5-332.7$ & 4.2 & 0.9 \\
\hline $\begin{array}{l}\text { New Center-Pivot } \\
\text { Acres at } \$ 6 \text { per Acre }\end{array}$ & 61.6 & 26.61 & $23.0-75.5$ & 1.3 & 0.5 \\
\hline $\begin{array}{l}\text { New 0ther Sprinkler } \\
\text { Acres at } \$ 6 \text { per Acre }\end{array}$ & 106.7 & 75.6 & $31.2-174.8$ & 0.7 & 0.03 \\
\hline
\end{tabular}

(a) Estimated average for all systems using Surface Water.

(b) Estimated average for all systems using Ground Water.

(c) Range of estimates across all water sources and subregions.

(d) Estimated potential for all systems regardless of cost per $\mathrm{kWh}$ saved.

(e) Estimated potential for all systems that can be achieved at a cost of 30 mills per kWh saved or less.

(f) Other Sprinkler includes handmove, sideroll, and solid-set sprinkler systems. 
SUMMARY TABLE 2. Cost per kWh Saved and Energy-Savings Potential for Improved Irrigation Scheduling on Non-Water-Sensitive Crops

\begin{tabular}{|c|c|c|c|c|c|c|}
\hline \multirow{2}{*}{$\begin{array}{c}\text { Improved } \\
\text { Scheduling Alternative }\end{array}$} & \multicolumn{3}{|c|}{ Cost per kWh Saved (1984 mills). } & & \multicolumn{2}{|c|}{ Energy Savings Potential (Mw) } \\
\hline & $\begin{array}{l}\text { Average } \\
\text { Swaj } \\
\end{array}$ & $\begin{array}{l}\text { Averpge } \\
\text { GW }\end{array}$ & Range $(c)$ & & $\begin{array}{c}\text { All } \\
\text { Applications (d) }\end{array}$ & $\begin{array}{r}30 \mathrm{Mil} / \mathrm{s} \\
\text { or Less }\end{array}$ \\
\hline $\begin{array}{l}\text { Existing Center-Pivot } \\
\text { Acres at } \$ 6 \text { per Acre }\end{array}$ & 56.0 & 21.0 & $14.8-114.0$ & & 15.5 & 10.5 \\
\hline $\begin{array}{l}\text { Existing 0ther Sprinkler } \\
\text { Acres at } \$ 6 \text { per Acre }\end{array}$ & 119.5 & 48.2 & $24.2-327.6$ & & 21.6 & 1.5 \\
\hline $\begin{array}{l}\text { New Center-Pivot } \\
\text { Acres at } \$ 6 \text { per Acre }\end{array}$ & 61.6 & 30.3 & $21.5-77.5$ & & 2.1 & 0.7 \\
\hline $\begin{array}{l}\text { New 0ther Sprinkler } \\
\text { Acres at } \$ 6 \text { per Acre }\end{array}$ & 107.9 & 61.6 & $37.5-163.0$ & & 3.5 & 0.1 \\
\hline $\begin{array}{l}\text { (a) Estimated average for all } \\
\text { (b) Estimated average for all } \\
\text { (c) Range of estimates across } \\
\text { (d) Estimated potential for a } \\
\text { (e) Estimated potential for a } \\
\text { (f) Other Sprinkler includes }\end{array}$ & $\begin{array}{l}\text { I systems } \\
\text { i systems } \\
\text { s all water } \\
\text { all systems } \\
\text { all systems } \\
\text { handmove, }\end{array}$ & $\begin{array}{l}\text { using Surfa } \\
\text { using Groun } \\
r \text { sources a } \\
\text { s regardies } \\
\text { is that can } \\
\text { sideroll, }\end{array}$ & $\begin{array}{l}\text { Water. } \\
\text { Water. } \\
\text { subregions. } \\
\text { of cost per kwh } \\
\text { achieved at a co } \\
\text { d solid-set sprir }\end{array}$ & $\begin{array}{l}\text { saved. } \\
\text { ost of } \\
\text { nkler }\end{array}$ & $\begin{array}{l}30 \text { mills per kWh } \\
\text { systems. }\end{array}$ & saved or 1 \\
\hline
\end{tabular}


occur as a result of reducing water withdrawals from the Pacific Northwest's hydroelectric system were not developed in this study.

Note that for both water-sensitive and non-water-sensitive crops, extreme variation is present in the cost per $k$ th saved estimates for systematic irrigation scheduling across water sources and subregions. This variation occurs for two reasons: 1) differences in total dynamic head requirements among subregions, water sources, and irrigation application systems; and 2) differences in water application volumes among subregions and irrigation application systems. The generally higher average iift requirements for groundwater irrigation translate into higher total dynamic head requirements. Thus, the cost per $k$ Wh saved estimates for improved irrigation when ground water is used are significantly lower than those of surface water installations. Higher water application volume requirements for irrigated crop production imply higher absolute levels of water and energy savings from improved irrigation scheduling. Thus, the cost per kWh saved estimates for high evapotranspiration subregions in the Columbia Basin area of Washington, north-central Oregon and southern Idaho are lower than for other subregions.

The variations in cost per $k$ wh saved estimates for improved irrigation scheduling imply that programs to promote improved scheduling should be selectively targeted to specific irrigation situations. In general, the situations where such programs will prove to be the most cost effective from a direct energy savings standpoint are those on high pumping lift installations in the major irrigation subregions. The costs per $k$ wh saved for systematic scheduling will normally be less than $30 \mathrm{mills}$ on sprinkler irrigation systems located in the major irrigation subregions that have pumping lifts exceeding 190 feet.

A substantial proportion of the total energy savings available from improved irrigation scheduling on center-pivot acres can be obtained for a cost of $30 \mathrm{mills}$ per $\mathrm{kWh}$ saved or less, because those pumping installations which offer the potential for relatively low costs per $k$ wh of savings also have the highest gross energy-savings potential. For example, the information presented in Summary Table 1 illustrates that approximately 78 percent of the potential energy savings on existing center-pivot water-sensitive crop acres could be 
obtained for a cost of $30 \mathrm{mills}$ per $\mathrm{kWh}$ saved or less for scheduling services costing six dollars per acre.

The benefits of improved scheduling will have to be thoroughly demonstrated through field testing before irrigators are willing to participate on a widespread basis in improved scheduling programs. In addition, because improved irrigation scheduling is primarily a labor- and knowledge-intensive conservation measure, it is believed that the rate of market penetration for improved scheduling will be significantly slower than for the "hardware"-based measures such as low-pressure irrigation.

Based on conversations with those experienced in operating improved scheduling services and an examination of the literature on scheduling, it is concluded that the most important element of an effective water management service is the knowledge and commitment of the individuals who direct and operate the service. For this reason, it is believed that scheduling methods that involve less than "full scheduling services" ${ }^{3}$ will generally not be as effective in reducing water/energy usage in the irrigation sector as will "full service" programs. At this time, it appears that the most feasible method of developing such full scheduling services is through the use of qualified individual consultants who have the knowledge and incentives to effectively perform the scheduling activities.

\section{RECOMMENDATIONS}

Based upon the findings developed during this study, it is recommended that the following activities related to improved irrigation scheduling be consi dered:

- development of field demonstration programs for improved scheduling services in the major irrigation areas of the Pacific Northwest, including provisions for detailed statistical analyses of the water

\footnotetext{
3 "Full scheduling services" involve, at a minimum, weekly or more frequent soil moisture-level monitoring during the growing season and the use of an evapotranspiration mode? of some type to analyze the timing and amounts of irrigations.
} 
use and crop yields of improved scheduling versus traditional scheduling

o development of estimates of the indirect energy savings that could occur through improved scheduling as a result of reductions in water withdrawals from the hydroelectric system.

The demonstration programs identified in the first recomnendation would provide a method of field testing the effectiveness of improved scheduling and would facilitate awareness of improved scheduling by irrigators. More extensive programs to provide scheduling services could be built from the demonstration programs at a later date. 


\section{CONTENTS}

SUMMARY

CONCLUSIONS AND RECOMMENDATIONS

ij

1.0 INTRODUCTION

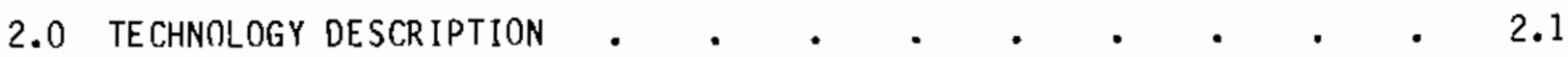

2.1 MONITORING SOIL MOISTURE CONTENT $\quad$ • . . . . . . 2.1

2.1.1 Feel Method Using Soil Probe or Auger . . . . 2.2

2.1.2 Use of an Evaporation Pan . . . . . . . 2.2

2.1.3 Gypsum Blocks or Resistance Blocks . . . . 2.2

2.1 .4 Tensiometers. . . . . . . . . . 2.3

2.1.5 Microwave Techniques . . . . . . . . 2.3

2.1 .6 Neutron Probe . . . . . . . . . 2.4

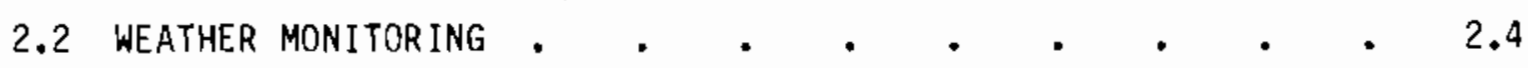

2.3 CROP NEEDS AND OTHER FACTORS TO CONSIDER IN IRRIGATION

2.3.1 Stage of Crop Growth . . . . . . . . 2.6

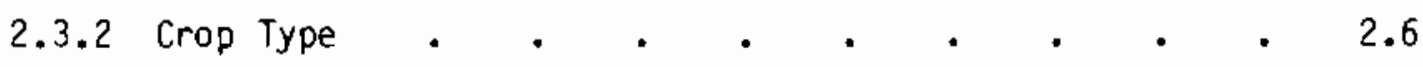

2.3.3 Leaching Requirements . . . • . . . 2.7

2.4 MEASUREMENT OF WATER VOLUME APPLIED.$\quad$ • . . . . 2.7

2.5 INTERPRETATION OF DATA AND THE DECISION TO IRRIGATE $\quad$ • 2.7

2.5.1 Continuous Irrigation And Periodic Irrigation . 2.8

2.5.2 Evapotranspiration Modeling . . . . . . 2.8

3.0 ALTERNATIVES CHOSEN FOR ANALYSIS AND ENERGY SAVINGS ASSUMPTIONS OF

EACH ALTERNATIVE

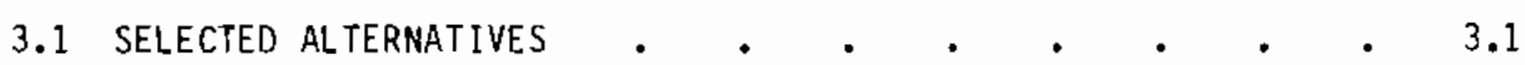

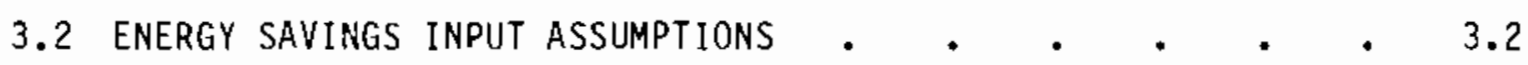

3.3 AODITIONAL BENEFITS OF SYSTEMATIC IRRIGATION SCHEDULING $\quad 3.8$ 


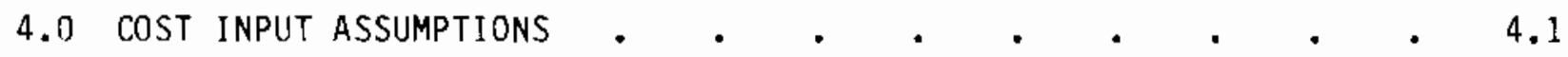

4.1 PER-ACRE CHARGES FOR IRRIGATION SCHEDULING $\quad \cdot \quad \cdot \quad \cdot \quad \cdot \quad 4.1$

4.2 SCHEDULING COST ESTIMATE SELECTED FOR USE IN THIS STUDY $\quad 4.4$

5.0 TECHNICAL LIMITS ON MEASURE APPLICATION AND CONSERVATION ALREADY

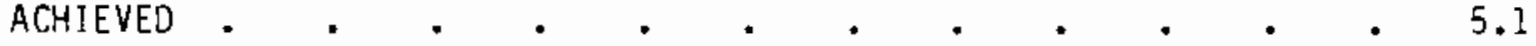

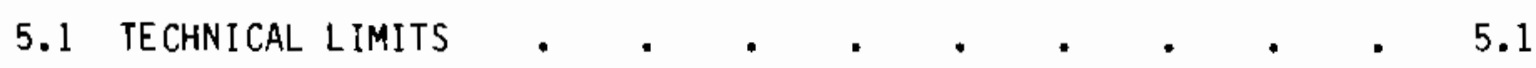

5.1.1 Technical Limits Due to Water Availability . . . 5.1

5.1.2 Technical Limits Due to Irrigation System . . . 5.3

5.1.3 Technical Limits Because of Crop Management Practices 5.3

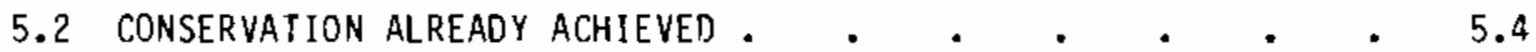

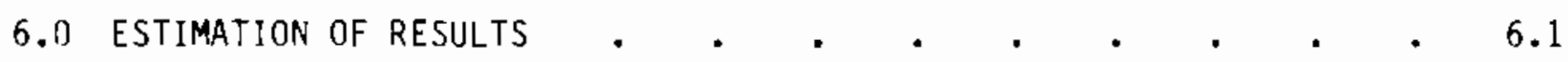

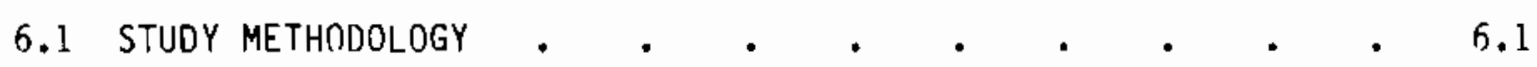

6.2 COST PER KWH SAVED AND ENERGY SAVINGS POTENTIAL FOR

SYSTEMATIC IRRIGATION SCHEDULING AT EIGHT DOLLARS

PER ACRE * * • • • • • • • • • 6.3

6.3 COST PER KWH SAVED AND ENERGY SAVINGS POTENTIAL FOR

SYSTEMATIC IRRIGATION SCHEDULING AT SIX DOLLARS

PER ACRE . . . . . . . . . . . . . . 6.9

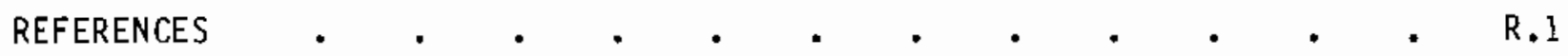




\section{FIGURES}

2.1 Factors that Should be Incorporated in Systematic Irrigation Scheduling

$\underline{\text { TABLES }}$

SUMMARY TABLE 1. Cost per $k$ wh Saved and Energy Savings Potential for Systematic Irrigation Scheduling vi i i

SUMMARY TABLE 2. Cost per kWh Saved and Energy Savings Potential for Improved Irrigation Scheduling on Non-Water Sensitive Crops

3.1 Types of Scheduling Alternatives Selected For Analysis . .

3.2 Estimates of the Percentage Reduction in Water/Energy Use That. Will Occur from Using Systematic Irrigation Scheduling Versus Traditional Scheduling Methods

3.3 Percent Reductions In Water/Energy Use from Using Systematic Scheduling Methods Versus Traditional Scheduling Methods That Were Selected for Use in This Analysis . . . . . 3.7

4.1 Per-Acre Costs of Providing Systematic Irrigation Scheduling Services

5.1 Model Input Assumptions: Conservation Achieved On Center-Pivot Acreage

5.2 Model Input Assumptions: Conservation Achieved On Other Sprinkler Acreage

5.3 Model Input Assumptions: Conservation Achieved On Groundwater Center-Pivot Acreage

5.4 Model Input Assumptions: Conservation Achieved On Surface Water Center-Pivot Acreage

5.5 Model Input Assumptions: Conservation Achieved On Groundwater Other Sprinkler Acreage

5.6 Model Input Assumptions: Conservation Achieved On Surface Water Other Sprinkler Acreage . . . . . . . . . .

6.1 Energy Savings Potential in Average MW and Cost per $k$ wh Saved in Mills for Using Systematic Irrigation Scheduling Services That Cost Eight Dollars per Acre on Existing Center-Pivot Acreages

6.2 Estimated Cumulative Energy Savings and Estimated Cumulative Acreages Impacted in 5-Mill Increments of Cost per kWh Saved on Existing Center-Pivot Acreages for Systematic Irrigation Scheduling Costing Eight Dollars per Acre 
6.3 Energy Savings Potential in Average MW and Cost per $\mathrm{kWh}$ Saved in Mills for Using Systematic Irrigation Scheduling Services That Cost Eight Dollars per Acre on Existing Handmove and Sideroll Acreages

6.4 Estimated Cumulative Energy Savings and Estimated Cumulative Acreages Impacted in 5-Mill Increments of Cost per kWh Saved on Existing Handmove and Sideroll Acreages for Systematic Irrigation Scheduling Costing Eight Dollars per Acre $\quad$ e $\quad$ • 6.8

6.5 Cost per $x$ Wh Saved in Mills for Using Systematic Irrigation Scheduling Services that Cost Six Dollars per Acre on Existing Center-Pivot, Handmove and Siderall Acreages . . . 6.10

6.6 Estimated Cumulative Energy Savings and Estimated Cumulative Acreages Impacted in 5-Mill Increments of Cost per kWh Saved on Existing Center-Pivot Acreages for Systematic Irrigation Scheduling Costing Six Dollars per Acre. . . . . . 6.11

6.7 Estimated Cumulative Energy Savings and Estimated Cumulative Acreages Impacted in 5-Mill Increments of Cost per kWh Saved on Existing Handmove and Sideroll Acreages for Systematic Irrigation Scheduling Costing Six Dotlars per Acre ${ }^{2} \cdot{ } \quad 6.12$

6.8 Estimated Cumulative Energy-Savings Potential (Avg. MW) in 5-Mi1l Increments of Cost per $\mathrm{kWh}$ Saved for Improved Scheduling on Existing Other Sprinkler waterSensitive Crop Acres

6.9 Estimated Cumulative Energy-Savings Potential (Avg. MW) in $5-M i 11$ Increments of Cost per $k$ Wh Saved for Improved Scheduling on New Other Sprinkler Water-Sensitive Crop Acres

6.10 Estimated Energy-Savings Potential in Average MW and Cost per kWh Saved in 1984 Mills for Improved Scheduling on Existing and New Other Sprinkler Non-Water-Sensitive Crop Acres

6.11 Estimated Cumulative Energy-Savings Potential (Avg. MW) in 5-Mill Increments of Cost per $k$ Wh Saved for Improved Scheduling on Existing Other Sprinkler Non-WaterSensitive Crop Acres

6.12 Estimated Cumulative Energy-Savings Potential (Avg. MW) in 5-Mill Increments of cost per $k$ Wh Saved for Improved Scheduling on New Other Sprinkler Non-WaterSensitive Crop Acres 


\subsection{INTRODUCTION}

Conservation was forecast to be the primary source of power for meeting the demands of the Pacific Northwest in a plan recently adopted by the Pacific Northwest Power Planning Council. Conservation in the irrigated agriculture sector was incorporated as an important component of the overall conservation effort in the Council's plan.

The Bonneville Power Administration (BPA) is expected to play a major role in the implementation of conservation programs in the region. In keeping with this role, BPA contracted with Pacific Northwest Laboratory to perform additional research on conservation in the irrigated agriculture sector. This report is the third in a series of four that will address the costs and energysavings potential of various conservation measures that could be used to reduce the energy used by irrigators in watering their crops.

In conjuction with its planning efforts, BPA required that specific information on the energy-savings potential (in average megawatts) and the cost per kilowatt-hour saved be developed for each conservation measure selected for analysis. To aid in this effort, a computer model of the irrigation energy consumption process, known as the Irrigation Sector Energy Planning (ISEP) Mode1, was developed by PNL personne1. The purpose of this report is to provide information on the input data provided to the ISEP model and the output results obtained from the model for a conservation measure defined as "improved irrigation scheduling."

Improved irrigation scheduling involves the use of systematic soil moisture and weather monitoring to determine the current and short-term future position of a crop with regard to the moisture level in the soil profile. The soit moisture and weather data are then used to scientifically determine the timing and amounts of irrigation applications. This measure has the potential to reduce the energy used in irrigation by reducing irrigation water use. Water that is not used is water that does not have to be pumped, and studies have shown that irrigators using traditional scheduling methods generally tend to apply more water than is required to support optimum crop growth.

The analysis of the energy-savings potential of improved irrigation scheduling presented in this report is limited to "direct" farm-level energy 
savings. The potential for "indirect" energy savings from increasing the amount of water available to generate power in the Pacific Northwest's hydroelectric system by using improved irrigation scheduling also exists. The analysis of indirect energy-savings potential is very complex, however, and is deferred for future study.

The report is divided into six chapters. In Chapter 2.0, the technical characterisitics of some methods of improved irrigation scheduling are briefly described. Chapter 3.0 identifies the specific types of improved scheduling alternatives that were chosen for use in the analysis, describes the water/energy savings input data that were used in analyzing each alternative, and identifies some potential benefits of improved scheduling that were not incorporated in this study. In Chapter 4.0, input data on the costs per acre for improved irrigation scheduling are described. Chapter 5.0 describes the technical limitations that may hinder the use of improved irrigation scheduling and provides information on the amount of conservation that may have already been achieved through the use of such scheduling. Finally, the report concludes with a description of the potential energy savings estimates and cost per kWh saved estimates that were obtained in the study. 


\subsection{TECHNOLOGY DESCRIPTION}

Energy consumption for irrigating crops is directly correlated with the amount of water applied. In some cases, water application volumes may exceed what the crop and the soil can beneficially use. Improved irrigation scheduling can increase the efficiency of water use by reducing this unnecessary water application.

Scheduling methods vary greatly in complexity and costs, but shared problems include the monitoring of soil moisture content, assessment of weather conditions, estimation of water requirements for a crop and field, and interpretation of data. In theory, a scheduling method should incorporate all the factors shown in Figure 2.1. In this chapter, a range of techniques that could potentially help farmers make informed water management decisions will be discussed. This discussion will facilitate an understanding of the specific scheduling alternatives that were selected for use in this study.

\subsection{MONITORING SOIL MOISTURE CONTENT}

The amount of moisture available to crops is a fundamental information requirement for optimal irrigation scheduling. Moisture applied in excess of

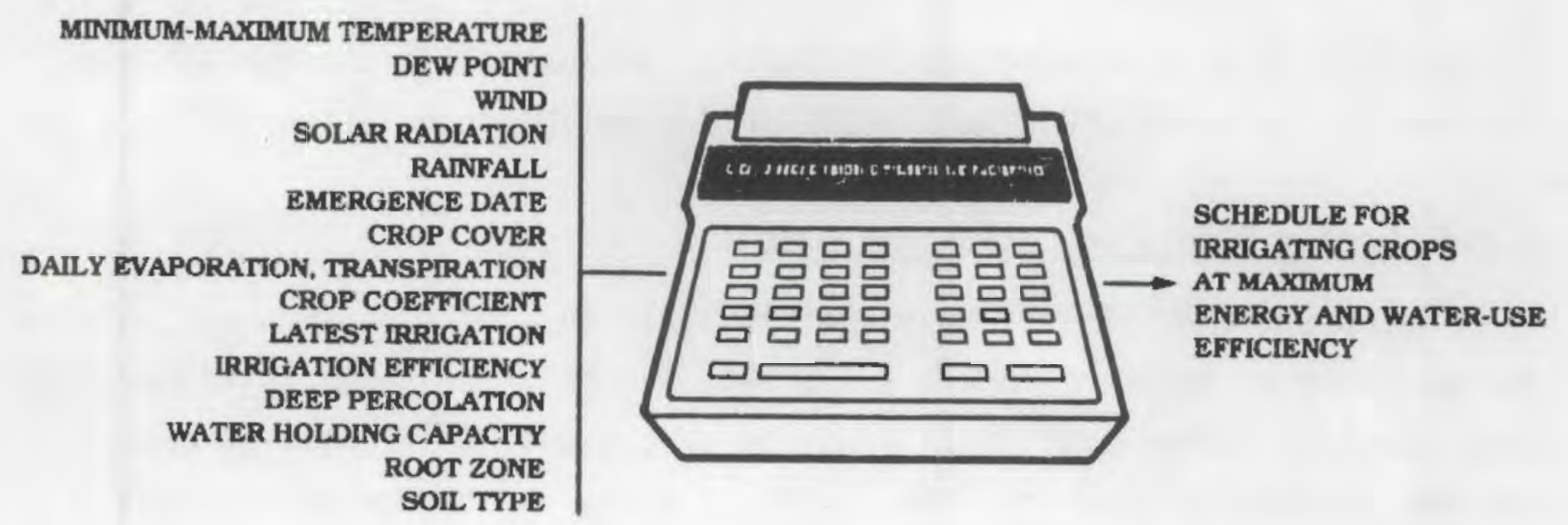

FIGURE 2.1. Factors that Should be Incorporated in Systematic Irrigation Scheduling 
the holding capacity of the soil is lost to crops, but crops may be permanently harmed if not enough water is available. The advantages and limitations to several techniques of measuring soil moisture content and availability will be discussed in this section.

\subsubsection{Feel Method Using Soil Probe or Auger}

The so-called "feel" method for determining soil moisture content involves deciding how much moisture is available in the soil on the basis of how a soil sample feels. A soil probe or auger can be used to collect a sample from the field. An experienced person can then estimate whether available moisture is adequate by interpreting clumping and other soil characteristics. According to some experts, the "feel" method can be accurate 90 percent of the time when used by experienced personnel (Crop Care Associates 1983).

\subsubsection{Use of an Evaporation Pan}

Evaporation measuring devices can be used in combination with crop consumptive water use data to estimate soil water losses. Evaporation pans installed under a sprinkler in the field can inexpensively indicate how much the level of usable moisture has changed since the last irrigation. More complicated evaporation equipment, such as Belani plate atmometers, may also be used. It is advisable to periodically check moisture content with a soil probe in conjunction with evaporation monitoring, because the technique assumes irrigations to field capacity (Sprinkler Irrigation Association 1975).

\subsubsection{Gypsum Blocks or Resistance Blocks}

The proportion of soil moisture available to plants depends not only on the quantity of moisture in the soil, but also on other factors influencing soil tension. Water availability may be affected significantly by contributions to osmotic pressure from dissolved salts and by how tightly soil moisture is held around soil particles. Electrical resistance blocks indirectly measure soil moisture tension and therefore account for factors 
affecting the availability of soil moisture not captured by volumetric measurements.

Electrical resistance blocks are generally made out of porous gypsum. Two wires imbedded in the blocks conduct electricity in proportion to the moisture content of the blocks, which is in turn proportional to the soil moisture tension where the blocks are buried (Sprinkler Irrigation Association 1975, Crop Care Associates 1983). Gypsum block readings are generally taken by portable conductance meters sold with the blocks. Gypsum blocks do not perform well in coarse-textured soils (Fischbach 1980a), may not give accurate readings where soil salinity is high (Crop Care Associates 1983), and can disintegrate under some alkaline conditions.

\subsubsection{Tensiometers}

A typical tensiometer has a hollow ceramic tip at the root-zone end attached by a closed tube to a measuring device at ground level. Water can be drawn from or into the tube by the surrounding soil. The internal pressure of a tensiometer simulates the osmotic pressure experienced by roots in drawing moisture from soil.

Tensiometers have been used at sites in Idaho (Wilton 1983) and Nebraska (Fishbach 1980b) to monitor moisture depletion and replenishment. Tensiometers do not require calibration, can measure moisture tensions from over wide ranges and may be connected to controllers for automatic irrigation systems (Sprinkler Irrigation Association 1975). They have been found to work satisfactorily in sandy soils where gypsum blocks cannot be used (Fishbach 1980b). However, tensiometers require frequent readings and servicing for good results (Wilton 1983) and are not easily moved from one field to another.

\subsubsection{Microwave Techniques}

According to Dr. Thomas Schmugge, NASA Goddard Space Flight Center, microwave observations of soil moisture can be made using both active (infrared) and passive (radiometric) techniques. However, current research indicates that direct observation of soil moisture is possible only to depths of two to five centimeters. Thus, according to Dr. Schmugge, the use of 
microwave observations to support irrigation scheduling in the United States is not likely in the near future.

\subsubsection{Neutron Probe}

Electronic instruments that use neutron measurenents to indicate soil moisture content are comercially available. A radioactive substance emits fast neutrons in the probe of a neutron instrument. Slow neutrons, created by the collision of these fast neutrons with hydrogen in soil moisture, are detected by a device built into the probe. A counting instrument records the rate of slaw neutron detection.

To measure soil moisture, the neutron probe is lowered to the desired measurement depth in the ground. The counter reading is converted to soil moisture content from calibration curves specific to the instrument used (Sprinkler Irrigation Association 1975). Neutron probe procedures can provide a successful basis for field-specific corrections of errors in computerized scheduling models (Buchheim and Ploss 1977).

The neutron probe and counter indicate percent moisture by volume and not moisture availability. The same probe can be used for soil moisture measurements in numerous locations, although measurements in a given field are taken at the same site each time. In the continuous cormercial use of neutron probes, precautions should be taken to minimize the radiation exposure of field personne].

\subsection{WEATHER MONITORING}

In theory, irrigation scheduling decisions should incorporate data on past and predicted weather patterns. Weather monitoring methods vary from basic observations of precipitation to complicated automated real-time data networks that track wind speed and direction, air temperature, humidity, solar radiation, soil temperature, and precipitation (Rosenberg et a1. 1983). In practice, constraints on the collection and interpretation of refined real-time weather data can limit their use.

Historical climate information is of ten incorporated into consumptive water use data. Actual and forecast weather conditions can then be used to revise previous estimates of evapotranspirative water use (Sprinkler Irrigation 
Association 1975, Crop Care Associates 1983). Anticipated water requirements in approaching weeks can be estimated from the historical probability of various weather conditions occurring in the region. Weather forecast data can be incorporated into the decision-making process on the order of days in advance.

A complex evapotranspiration model is more useful than more approximate models only if sufficiently refined data are available for use in the model. Conversely, it is not useful for purposes of improved irrigation managenent to measure all pertinent envirominental data hourly unless a complex evapotranspiration model is available. In a Nebraska evaluation of the use of climate data for improved irrigation management, it was concluded that hourly environmental data improves daily evapotranspiration estimates with a fairly complex model while such data do not affect results of simpler modeis (Rosenberg et al. 1983).

The Nebraska program for the use of climate information to support irrigation scheduling seems to demonstrate that a high degree of automation in data collection and transfer, and a strong compitment by organizations associated with the efforts, will improve some evapotranspiration modeling results. In the Nebraska study, variations in the net application of water by center pivots were significantly reduced by adjustments in the speed of pivot rotation based on hourly weather data (Rosenberg et al. 1983). According to Dr. Jim Koss, of the Statistical Climatology Branch at the National Oceanic and Atmospheric Administration, the automated weather data networks seem to successfully provide weather data earlier than climate information can be published by the National Climatic Data Centers and in forms unavailable through the National Weather Service alone.

\subsection{CROP NEEOS AND OTHER FACTORS TO CONSIOER IN IRRIGATION SCHEOULING}

Because the goal of improved irrigation scheduling is to improve the efficiency of water use, it is important to clearly identify the factors that determine the correct scheduling of irrigation water applications. These factors are briefly discussed below. 


\subsubsection{Stage of Crop Growth}

The stage of crop growth influences the required timing and amounts of irrigation applications by affecting both the consumptive water use and the anount of evapotranspiration that occurs. Generally, crops have higher levels of consumptive water use when their root systems are fully developed than during germination. However, full crop cover can reduce the anount of evapotranspiration that occurs from the soil. This effect is somewhat offset by the reduction in water penetration that occurs under conditions of full crop cover. The inability to correctly account for the impacts of the stage of crop growth on water requirements appears to be a major problem with the traditional scheduling methods used by many farmers. After studying irrigation scheduling patterns in Oregon for 25 years, it was generally concluded that farmers underwater in the peak sumer period and overwater early and late in the growing season. 1

\subsubsection{Crop Type}

The amounts of irrigation water needed by specific crops in various soils are published as consumptive use data by various branches of the Oepartment of Agriculture. These data, which generally are available as irrigation guides from local branches of the Soil Conservation Service, can be important inputs in evapotranspiration modeling. In general, crop yields may suffer if depletion of total available moisture in the effective root zone exceeds 50 percent of field capacity (Sprinkler Irrigation Association 1975). However, both the occurrence and the impacts of soil moisture depletion are highly dependent on the type of crop being grown.

Crop irrigation needs can be monitored to some extent through field detection of plant stress. For example, bean plants may indicate watering needs by changing color before other adverse effects occur. However, visible plant stress generally indicates that yields or quality have already been

1 Personal communication with Marvin Schearer, Department of Agricultural Engineering, Oregon State University, March 1984. 
adversely affected by water limitations, and the signs of moisture stress will differ from one crop to another. Infrared photography may aid in the detection of plant stress and is sometimes used by commercial scheduling services to supplement other information on crop requirements (Jensen 1978).

\subsubsection{Leaching Requirements}

Irrigation requirements include water use for adequate leaching in addition to crop consumptive use. It is important to ensure enough water outflow to prevent accumulation of soluble salts and specific toxic ion concentrations in the root zone. The maximum attainable irrigation efficiency decreases as the concentration of soluble salts in the water increase "regardless of how well the irrigation system was designed, constructed, and operated" (Jensen 1975).

\subsection{MEASUREMENT OF WATER VOLUME APPLIED}

The volume of water actually applied to a field at each watering depends on the design of the irrigation system as well as on management practices. Design considerations include field size, number of sprinklers and their operating pressures, soil type, water source and maximum water requirements. In general, rough estimates of water volume applied are developed based on sprinkler discharge rates and duration of water applications.

It is possible, although not comon practice, to accurately measure applied gallonage with the use of a flow meter. Flow can be measured in distribution pipes or at the end of pump discharge pipes in terms of both gallons per minute and total gallonage. In general, flow meters which measure the pressure differential, or head, across some restriction in the flow path would be feasible measurement instruments (Considine 1983). Pressure measurements from head-type flow meters can be converted to flow rates with the use of engineering charts (Sprinkler Irrigation Association 1975).

\subsection{INTERPRETATION OF DATA AND THE DECISION TO IRRIGATE}

Scheduling practices vary widely between irrigators. Some or all of the factors affecting the amount of water that is available to the crop (soil, 
plant, and atmospheric conditions) may be incorporated into irrigation planning, by the farm manager alone or with the support of sophisticated computer models. Scheduling methods currently in use are discussed in this section.

\subsubsection{Continuous Irrigation And Periodic Irrigation}

Because of the characteristics of their irrigation water supply systems, many farmers irrigate either continuously or periodically regardless of the consumptive needs of the crops they are growing. For example, a significant proportion of surface water gets delivered periodically to irrigators (Rosenberg et al. 1983, Jensen 1975). Applying irrigation scheduling on acres with water supplied in this periodic manner may be more difficult because farmers are constrained by the timing of water availability.

Continuous irrigation may be practiced on acres where crop needs are perceived to continuously exceed pumping capacity. Acres serviced by wells with low capacity may have little potential for energy savings through improved scheduling (Rosenberg et al. 1983) because the farmer is already applying less water than the crop requires.

Although some irrigators may be constrained in making their irrigation scheduling decisions, other irrigators use non-systematic methods such as continuous and periodic irrigation simply because these are the methods that have always been used. Often irrigators have not made the investment in time and money that is required to use more systematic methods of scheduling.

\subsubsection{Evapotranspiration Modeling}

When possible, an irrigator should interpret conditions of the climate, crop, soil moisture content and stage of growth in deciding when to irrigate a field. Although an experienced person with access to field data could probably make decisions similar to those arrived at by computerized models, computerized models can significantly reduce the amount of time required to perform scheduling calculations.

Several models based on a sophisticated water budget are in use comercially. The models incorporate several soil, plant, and atmospheric 
parameters into estimates of actual and potential evapotranspiration or crop water use. An irrigation is scheduled when evapotranspiration reaches a predetermined value (Crop Care Associates 1983). An example of an evapotranspiration equation developed by a commercial scheduling service is presented below.

$$
E T_{\text {crop }}=\left(K_{c}+K_{s}+K_{e}\right) \times E T_{r}
$$

where $E T_{\text {crop }}=$ the water use of the crop

$K_{c}=$ the crop coefficient

$K_{s}=$ the soil drying coefficient

$K_{e}=$ the soil evaporation coefficient

$E T_{r}=$ the reference crop evapotranspiration

What is occurring in the above equations is that the $E T_{r}$ for a given day is being adjusted by three coefficients $\left(K_{c}, K_{s}, K_{e}\right)$ until it represents the actual ET of the crop. The ET $r$ values for past and current days are calculated from climatic data. $\mathrm{ET}_{r}$ values are interpolated from the forecasted ET $r$ curve in predicting future soil depletions. As the model calculates into the future, the ET crop values accumulate until the allowable depletion is reached. At this point, another irrigation is scheduled.

Some evapotranspiration models are yield-maximizing models while others are profit maximizing. Evapotranspiration models that weigh benefits of crop yield response against the cost of irrigation water application may ultimately serve farmers better than models based only on yield maximization (Biere et al. 1981). From a farmer's point of view, an irrigation should be scheduled when profitable, rather than when evapotranspiration reaches a pre-determined value. However, determining the profitability of irrigation in specific situations is a complex problem. Some models claim to solve this problem (Crop Care Associates 1983), while others do not.

The methods of supplying irrigators with scheduling information and recomendations are potentially unlimited. They range from the publication of simple evapotranspiration statistics in farm publications to providing complete scheduling services (including soil fertility management) for farmers. 
However, in a recent study of the potential for the adoption of improved irrigation scheduling in the Pacific Northwest, it was found that irrigators generally will not adopt improved scheduling methods where they are responsible for managing the scheduling themselves, except on water-sensitive crops (Merchant and Herman 1984). Thus, it is believed that scheduling prograns that do not include initial management by someone other than the irrigators themselves will generally not be popular or effective in most Pacific Northwest farming situations. 


\subsection{ALTERNATIVES CHOSEN FOR ANALYSIS AND ENERGY SAVINGS ASSUMPTIONS OF EACH ALTERNATIVE}

Although the potential types of scheduling programs that could be offered to farmers are potentially unlimited, it is necessary for purposes of this study to narrow the possible alternatives to a number that is feasibie for analysis. In addition, it is necessary to attempt to identify the potential savings in water and energy that may be associated with the use of the selected irrigation scheduling alternatives. It should be noted that the potential savings that may result from irrigation scheduling programs in the Pacific Northwest have not been thoroughly researched and, thus, the numbers selected for use in this analysis should not be regarded as final estimates. However, until additional field test results are available, it is believed that the estimates used in this study are the most representative available.

In this chapter, the improved scheduling alternatives selected for use in this study are described, and representative estimates of the potential savings in water and energy that could be realized from the use of these alternatives are identified. The chapter concludes with a description of some potential benefits of improved irrigation scheduling that are not incorporated in this analysis of the direct farm-level energy savings available from such scheduling.

\subsection{SELECTED ALTERNATIVES}

The irrigation scheduling alternatives selected for use in this analysis and their characteristics are shown in Table 3.1. Note that both of the selected alternatives involve frequent soil moisture monitoring activities by fieldmen and the use of some type of evapotranspiration model to schedule irrigations. Based upon the results of current and past efforts to encourage farmers to systematicaliy schedule their irrigations, it is believed that such efforts will not be successful without substantial involvement by trained field personnel, at least during the early years of the program (Merchant and Herman 1984). Simply providing farmers with educational materials and general data will normally not induce farmers to improve their irrigation scheduling, except on water-sensitive crops where higher yields are the goal of using improved scheduling methods. 
TABLE 3.1. Types of Improved Scheduling Alternatives Selected For Analys is

Scheduling Alternative

Full Scheduling

Soil Moisture Monitoring

\section{Characteristics}

- Weekly or more frequent soit moisture monitoring by fieldmen

- Use of weather stations

- Use of neutron probes for soil moisture monitoring

- Use of an evapotranspiration model to calculate consumptive water use and schedule irrigations

- Weekly or more frequent soil moisture monitoring by fieldmen

- Use of an evapotranspiration model to calculate consumptive water use and schedule irrigations

The only difference between the two alternatives selected for analysis is the use of weather stations and neutron probes to aid in the scheduling activities. It is assumed that weather data would also be incorporated in the "soil moisture monitoring" scheduling alternative but that this weather data would be of a very general nature and would not be collected on a site-specific basis. The "feel method" of soil moisture monitoring is also assumed for use in the soil moisture monitoring scheduling alternative.

The use of site-specific weather stations and neutron probes could lead to some improvement in the effectiveness of irrigation scheduling programs. In addition, the discussion presented in Chapter 4.0 will demonstrate that the additional costs of purchasing weather stations and neutron probes are relatively low when allocated on a per-acre basis.

\subsection{ENERGY SAVINGS INPUT ASSUMPTIONS}

For a scheduling program, the reductions in energy use that result from the use of the program are directly proportional to the reduction in water use 
that occurs during the program. However, the reduction in water use that will occur from using a scheduling program will depend on many factors, including the following:

- the degree to which farmers monitor and control their soil moisture water levels and applications prior to becoming involved in a scheduling program

0 the type of crops being grown and the perceived financial risks associated with the underwatering of these crops

o the degree of trust that irrigators have in the irrigation scheduling recommendations developed by the field personnel

- the ability of irrigators to control and measure the amounts of water that they apply to the ir crops.

The factors listed above cause the amount of water and energy savings that should be expected from the use of improved irrigation scheduling in any specific farming situation to be highly variable. However, a number of evaluations of the effectiveness of scheduling have been performed. The results of these analyses are listed in Table 3.2. Note that some of the results were gathered from published information while others were obtained from unpublished information. Some of the results were obtained using statistical methods, while others are subjective estimates developed by qualified experts. Some of the estimates of scheduling effectiveness were developed in California, where higher prices for water and energy and longer crop growing seasons cause the use of systematic irrigation scheduling methods to be more prevalent than in the Pacific Northwest.

All of the estimates of the effectiveness of scheduling presented in Table 3.2 are based on comparisons to situations where no systematic method of soil moisture measurement and evaluation is used. The marginal effectiveness of irrigation scheduling is believed to decline as the complexity of the scheduling system being used increases. For example, use of a complex computerized scheduling program on one large farm was estimated to result in 
TABLE 3.2. Estimates of the Percentage Reduction in Water/Energy Use That Will Occur from Using Improved Irrigation Scheduling Versus Traditional Scheduling Methods

Source of Estimat
Published data
developed by the
U.S. Bureau of
Reclamation,
Lake Chelan, WA
(1983)

Soil Conservation

Service

Boise, 10

(Wiiton 1983)

Published data developed by J.M. Lord, Fresno, CA (Lord and Gartang 1981)

Unpubli shed estimates developed by

Crop Care Associates

Fresno, CA

Published estimates developed by

James A. Larson and cited in (Rosenberg et al. 1983)

Published information from the Soil

Conservation

Service

Bozeman, Montana (USDA 1978)
Estimate of Reduction in Water/Energy Use That will Occur from Using Improved

Method by which Estimate Was Developed

Analysis of field records on the amount of water that would have been applied using systematic scheduling versus what was actualiy applied on 6000 acres of apples

Analysis of tensiometer and consumptive use field tests on apples

1 irrigation per year or 8 to $14 \%$ on apples

$13 \%$ on apples

Statistical comparisons of water use on systematically scheduled versus traditionally scheduled fields

$31 \%$ on sprinkler-irrigated grain $35 \%$ on gravity-flow irrigated tomatoes

Analysis of experience gained through providing private scheduling services

$20 \%$ to $30 \%$ on a 11 crops

Use of a simulation model to estimate water application amounts on corn under various scheduling methods

Evaluation of the potential water conserving management practices that could be applied in the Upper Columbia subregion
$20 \%$ on corn

$26 \%$ on a 11 crops 
TABLE 3.2 (contd.)

Estimate of Reduction in Water/Energy Use That Will

Method by Which Source of Estimate Estimate Was Developed

Occur from Using Improved

\begin{tabular}{|c|c|c|}
\hline $\begin{array}{l}\text { Unpublished data } \\
\text { from Umatilla } \\
\text { Electric Cooperative } \\
\text { on the results of } \\
\text { their scheduling } \\
\text { program }\end{array}$ & $\begin{array}{l}\text { Analysis of field records } \\
\text { on the average amounts of } \\
\text { water applied by farmers } \\
\text { in the scheduling program } \\
\text { versus traditional } \\
\text { application volumes }\end{array}$ & $\begin{array}{l}26 \% \text { on past } \\
29 \% \text { on pota } \\
31 \% \text { on whea } \\
35 \% \text { on corn } \\
39 \% \text { on a } 1 \mathrm{fa}\end{array}$ \\
\hline $\begin{array}{l}\text { Published estimates } \\
\text { developed by } \\
\text { P. Fischbach of } \\
\text { Nebraska } \\
\text { (Fischback } 1980 \mathrm{~b} \text { ) }\end{array}$ & $\begin{array}{l}\text { Comparison of water applied } \\
\text { on field plots using } \\
\text { various scheduling methods to } \\
\text { traditional water applications }\end{array}$ & $53 \%$ on \\
\hline $\begin{array}{l}\text { Previous Pacific } \\
\text { Northwest Power } \\
\text { Planning Council } \\
\text { study }\end{array}$ & $\begin{array}{l}\text { Analysis of empirical } \\
\text { results from a Department of } \\
\text { Energy study of scheduling } \\
\text { effectiveness }\end{array}$ & $24 \%$ \\
\hline $\begin{array}{l}\text { Melvin Campbell } \\
\text { Famm Manager } \\
U \text { and I Inc. }\end{array}$ & $\begin{array}{l}\text { Comparison of water appli- } \\
\text { cation data on fields using } \\
\text { improved scheduling to } \\
\text { application when no form of } \\
\text { improved scheduling is used }\end{array}$ & $20 \%$ to $40 \%$ \\
\hline
\end{tabular}

(a) Lower-bound estimates of the percent savings that occurred from using improved scheduling on selected fields. 
only a 5 percent reduction in water use compared to a slightly less rigorous system that had been used previous ly. ${ }^{1}$

Although the estimates presented in Table 3.2 vary from one source to another, some general inferences can be made from the data. These inferences include:

o The effectiveness of improved scheduling in terms of saving water is lower for orchard crops than for field crops.

- The effectiveness of the introduction of improved scheduling methods on water-sensitive crops, such as potatoes, would appear to be lower than for other field crops because these crops are irrigated more efficiently using traditional methods than are other crops and because the perceived risks of underwatering these crops are greater.

- In most cases, the water savings reductions from using improved scheduling methods versus traditional scheduling methods on field crops will range from 20 to 35 percent of the current water usage.

- In most cases, the water savings effectiveness from using improved scheduling versus traditional scheduling methods on orchard crops will range from 10 to 15 percent of the current water usage.

Selection of input parameters for use in this study that will be representative of the average savings that will occur from the use of systematic scheduling is necessarily an arbitrary procedure. However, based on an examination of available field test results, it appears that appropriate conservative values for the percent reduction in water use that could occur from the use of systematic scheduling in the Pacific Northwest are those shown in Table 3.3. Note that the input values selected for use in this study were generally selected from the lower range of the estimates presented in Table 3.2 .

Note from Table 3.3 that the representative water/energy use reductions for other sprinkler irrigation systems are generally 40 to 50 percent less than

1 Personal communication with Melvin Campbe11, Irrigation Manager, $U$ and I Incorporated, Kennewick, Washington, February 1984. 
TABLE 3.3. Percent Reductions in Water/Energy Use from Using Improved Scheduling Methods versus Traditional Scheduling Methods That Were Selected for Use in This Analysis

Type of Irrigation System

Center Pivot Other Sprinkler(a)
Wheat

22

Selected Percent Reduction By Crop

\begin{tabular}{lcccc} 
Alfalfa & Potatoes & Corn & Orchard & 0ther \\
\cline { 3 - 4 } 22 & 20 & 22 & 12 & 22 \\
12 & 10 & 12 & 7 & 12
\end{tabular}

(a) Includes sideroll, handmove, and solid-set systems.

the representative reductions for center-pivot systems. These results were not noted in any of the published or unpublished field studies examined in this study. Changing the number and duration of irrigation water applications would appear to be no more difficult on other sprinkler systems. However, an expert with 25 years of experience in working with irrigation scheduling programs stated that it is very likely that improved irrigation scheduling would be less effective on other sprinkler systems. 2 To reflect this consideration, the representative estimates of irrigation scheduling effectiveness for centerpivot systems were arbitrarily reduced by 40 to 50 percent to derive representative estimates of scheduling effectiveness for other sprinkler systems.

Note from Table 3.3 that no attempt was made to attach a value to the marginal increase in water savings that may be associated with the use of weather stations and neutron probes. Some experts believe that use of the "feel" method is nearly as effective as neutron probe measurement (Crop Care Associates 1983). Other experts report that a well-calibrated neutron probe is

2 Personal communication with Marvin Shearer, Department of Agricultural Engineering, Oregon State University, March 1984. 
much more effective than subjective "feel" methods in measuring soil moisture. 3 This expert also reports that weather stations are necessary for effective scheduling on center-pivot systems while on other irrigation systems they are not. ${ }^{4}$ in any case, cost information presented in Chapter 4 will demonstrate that the costs of weather stations and neutron probes are very low when evaluated on a per-acre basis over a 20-year system 1 ife.

Throughout our analysis it is assumed that before improved scheduling is implemented, all sprinkler irrigation systems have been converted to lowpressure irrigation and their fittings and mainlines have been modified to reduce energy usage. Based on current activities underway in the irrigation sector, it is believed that these irrigation conservation measures are likely to be implemented before improved scheduling. Thus, the energy-savings potential and the costs per $k$ wh saved for improved irrigation scheduling developed in this study are based on the savings levels that would be expected for well-designed low-pressure sprinkler systems. The application head assumed for a well-designed low-pressure center pivot is 90 feet at the pivot. The application head assumed for a well-designed low-pressure other sprinkler system is assumed to be 95 feet at its source point.

Gravity flow systems will not be included in the analysis of improved scheduling. It is believed that water application measurements are too imprecise on gravity flow systems for improved scheduling methods to be effective. This issue, along with other potential limitations to the use of improved scheduling, is discussed more fully in Chapter 5.

\subsection{ADDITIONAL BENEF ITS OF IMPROVED IRRIGATION SCHEDULING}

Improved irrigation scheduling will likely provide benefits not explicitly accounted for by direct farm-level energy savings. The exclusion of these

3 Personal communication with Melvin Campbell, Irrigation Manager, $U$ and 1 Incorporated, Kennewick, Washington, February 1984.

4 Personal communication with Melvin Campbe11, Irrigation Manager, U and I Incorporated, Kennewick, Washington, February 1984. 
indirect scheduling benefits from the assessment of energy savings from scheduling may cause the estimates of costs per kilowatt-hour saved developed in this study to be upwardly biased.

One of the major benefits that is excluded from this analysis is the potential for improved irrigation scheduling to result in increased water supplies within the Pacific Northwest's hydroelectric system (Davenport et al. 1981). These additional supplies could be used to generate more hydroelectric power and/or to enhance fish runs within the region's rivers and streams. It is generally believed that the indirect loss of energy from withdrawing water from the region's hydroelectric system for irrigation is significantly larger than the direct use of energy for irrigation pumping. Thus, inclusion of the indirect energy savings from reduced water usage through improved scheduling could have a significant impact upon future studies of the energy-conservation potential of improved scheduling.

Although the exclusion of changes in hydrogeneration potential only affects the estimates developed for scheduling on surface water acres, additional benefits may accompany scheduling on groundwater acres. Depletion of groundwater tables, with associated needs for increasingly deep wells, may be reduced if irrigation management reduces farm water demand (Davenport et a1. 1981). On the other hand, reduced runoff and deep percolation may slow the rate of well recharge and partially cancel the benefits of reduced overdraft. The net effect on groundwater tables and indirect energy savings cannot be analyzed without further information.

The principal purpose of irrigation management, in many cases, is not to save water or power but rather to provide more optimal growing conditions for crops. ${ }^{5}$ Many studies have found that the use of systematic irrigation scheduling can increase both crop yields and crop quality, particularly on water-sensitive crops like potatoes and corn. For example, one study found

\footnotetext{
5 Personal comunication with Larry King, Agricultural Extension Agent, Montana State University, Bozeman, Montana, February 1984.
} 
opportunities for decreased malformation of tubers and improved yields from properly timed potato irrigation (Locke 1984). Another study cited potentially significant losses of nitrogen available to corn when overwatering carries water-soluble nutrients below the root zone (Fischbach and Hoover 1978). Yet another study of crop yield data found that corn yields were increased when systematic irrigation scheduling recomendations were closely followed. ${ }^{6}$ Because of the greater likelihood for improved crop yields on water-sensitive crops like corn and potatoes, it seems likely that the rate of irrigators' acceptance of improved scheduling will be more rapid on water-sensitive crop acres. A market study of improved irrigation scheduling in the Pacific Northwest revealed that this is indeed the case. To reflect this consideration, our analysis of improved irrigation scheduling was partitioned into water-sensitive crops (potatoes, corn, and other miscellaneous crops) and non-water-sensitive crops (wheat, hay, orchard, and other miscellaneous crops).

6 Personal communication with Meivin Campbell, Irrigation Manager, $U$ and I Incorporated, Kennewick, Washington, February 1984. 


\subsection{COST INPUT ASSUMPTIONS}

The costs of providing improved scheduling services will vary according to the level of services provided. However, as stated previously, it is believed that improved scheduling will not achieve acceptable levels of effectiveness and penetration unless relatively complete scheduling services, with frequent soil moisture-level monitoring, are provided. In other areas, where the use of improved irrigation scheduling is more widespread, complete scheduling services have normally been provided by private consultants who assess a per-acre charge for the services. Thus, the levels of these per-acre charges are assumed to appropriately represent the costs of improved scheduling services. In this section, information on the costs of improved scheduling services is presented.

\subsection{PER-ACRE CHARGES FOR IRRIGATION SCHEDULING}

Improved irrigation scheduling is primarily a labor-intensive activity, while the majority of the energy conservation measures that could potentially be applied in the irrigation sector are capital-intensive equipment modifications. By far the largest cost of improved scheduling is incurred in paying the salaries of the field personnel who perform the irrigation scheduling. However, these personnel are the most important component of an effective irrigation scheduling program.

Various estimates of the per-acre costs associated with providing improved irrigation scheduling services are presented in Table 4.1. All of the estimates presented in Table 4.1 are based upon actual per-acre charges and/or experience gained through conducting improved irrigation scheduling programs.

All estimates presented in Table 4.1 include an allowance for profit for those performing the service. In addition, some of the costs shown in Table 4.1 inciude the costs of providing soil fertility management services. The two highest cost estimates are for California locations, where higher crop values and generally higher price levels allow for higher prices to be charged for providing scheduling services.

It seems likely that through the sponsorship of BPA and public utilities, the costs of providing improved scheduling could be reduced to the five to 
seven dollar per acre range because the sponsors would not require an allowance for profit on their investment. However, without the involvement of private consulting firms in the provision of scheduling services, it is probable that the effectiveness of the improved scheduling programs will be reduced. ${ }^{1}$ In California, Pacific Gas and Electric has chosen to provide rebates to farmers for participating in irrigation scheduling programs rather than directly organizing and performing the scheduling services themselves. ${ }^{1}$ At this point in time, it appears that this would also be the most appropriate method for BPA to use in facilitating the use of improved scheduling, if such facilitation is determined to be appropriate.

\section{TABLE 4.1. Per-Acre Cost Estimates for Providing Improved Irrigation Scheduling Services}

\begin{tabular}{lc}
\multicolumn{1}{c}{ Source } & Per-Acre Cost (\$) \\
Crop Care Associates & $\begin{array}{l}\$ 7.90 \text { to } \$ 10.50 \text { (including } \\
\text { fertility management) }\end{array}$ \\
J.M. Lord, Inc. & $\$ 8.00$ \\
U and I Incorporated & $\$ 7.85$ \\
Umatilla Electric Co-op & $\$ 6$ to $\$ 10$
\end{tabular}

The capital costs associated with the purchase of neutron probes and weather stations will have little impact upon the total per-acre costs of systematic scheduling programs. The initial cost of purchasing a weather station can range as high as $\$ 10,000^{2}$ but can also be as little as

1 Personal communication with Joe Lord, private irrigation scheduling consultant, Fresno, California, February 1984.

2 Personal communication with Fred Ziari, irrigation scheduling consultant with Umatilla Electric Co-op, Hermiston, Oregon, February 1984. 
$\$ 4500 .^{3}$ One weather station would generally be capable of covering at least 10,000 acres. 4 Neutron probes generally cost approximately $\$ 4000$ per unit (Crop Care Associates 1983) and are capable of covering approximately 5000 acres. 5 No basis exists for assuming that weather stations or neutron probes would not last 20 years. ${ }^{6}$ Calculation of the annual cost per acre for weather stations and neutron probes using these cost estimates and a 3 percent real discount rate (which equates to a 0.0672 capital recovery factor (CRF) over 20 years) is illustrated as follows:

$$
\begin{aligned}
& \$ 10,000 \text { per weather station } \div 10,000 \text { acres per station } \\
& x 0.0672 \mathrm{CRF}=7 \not \text { per acre } \\
& \$ 4,000 \text { per neutron probe } \div 5,000 \text { acres per probe } \\
& \times 0.0672 \mathrm{CRF} \\
& =5 \notin \text { per acre } \\
& \text { Total Annual Cost } \\
& =12 \not \text { per acre }
\end{aligned}
$$

When compared to the costs of the labor and management necessary to execute improved scheduling activities, 12 cents per acre is insignificant. Thus, no difference in costs is assumed in our study between scheduling programs that use weather stations and neutron probes, and scheduling programs that do not use them. It is believed that the costs of the additional education and training of personnel that would be necessary to accurately schedule irrigations using the "feel" method of moisture measurement would likely offset the additional costs for weather stations and neutron probes.

3 Personal communication with Melvin Campbell, Irrigation Manager, $U$ and I Incorporated, Kennewick, Washington, February 1984.

4 Personal communication with Melvin Campbe11, Irrigation Manager, $U$ and I Incorporated, Kennewick, Washington, February 1984.

5 Personal communication with Melvin Campbell, Irrigation Manager, $U$ and I Incorporated, Kennewick, Washington, February 1984.

6 Personal communication with Fred Ziari, irrigation scheduling consultant with Umatilla Electric Co-op, Hermiston, Oregon, February 1984. 


\subsection{SCHEDULING COST ESTIMATE SELECTED FOR USE IN THIS STUDY}

After examining the available scheduling cost estimates presented in Table 4.1, \$6 per acre was selected as the most representative estimate of the current cost of obtaining improved irrigation scheduling for irrigated acres in the Pacific Northwest. This compares to a $\$ 5$ per acre charge used in a previous study performed for the Pacific Northwest Power Planning Council (Harrer 1982).

It should be emphasized again that the $\$ 6$ cost selected for use in this study assumes that full scheduling services, including continuous soil moisture monitoring, would be provided. However, the cost selected for use in this study is generally in the low range of the estimates shown in Table 4.1 because: 1) the costs of providing soil fertility managenent services are not included in the $\$ 6$ cost; 2) the costs in the Pacific Northwest for full scheduling services should be lower than those in California; and 3) the costs of scheduling services can be reduced by BPA and irrigators sharing the costs.

Because it is assumed that improved scheduling would be paid for on an annual per-acre basis, all scheduling costs should be regarded as additional annual operating and maintenance costs for irrigation. Thus, it is not necessary to allocate any direct capital costs for improved scheduling over an estimated measure life. 


\subsection{TECHNICAL LIMITS ON MEASURE APPLICATION}

AND CONSERVATION ALREADY ACHIEVED

The purpose of this chapter is to provide information on acres that should be excluded from estimates of potential energy savings because of technical limits or achieved conservation. Technical limits--which may take the form of inflexibility in existing irrigation systems, water availability or nonirrigation crop requirements--are discussed in Section 5.1. Estimates of acres excluded from further analysis because of conservation already achieved are explained in Section 5.2.

\subsection{TECHNICAL LIMITS}

When existing irrigation practices are inflexible, technical limits to improved irrigation scheduling should be applied. However, some of the factors discussed in this section diminish potential savings from irrigation scheduling but do not preclude them. Potential technical limitations to improved scheduling caused by water availability problems are discussed in Section 5.1.1. Technical limits related to the adaptability of water application systems and non-irrigation crop management practices are considered in Sections 5.1 .2 and 5.1 .3 , respectively.

\subsubsection{Technical Limits Due to Water Availability}

Farmers need to be able to fine-tune the frequency and volume of water deliveries for modern scheduling methods to work. In some circumstances, both surface water and groundwater sources may lack the desired flexibility. Rigidity in the timing of surface water deliveries to farms by irrigation districts, and low well capacities that constrain the rate of groundwater delivery may occasionally limit the applicability of improved scheduling.

The same surface water delivery system that a farmer believes to be too inflexible for systematic scheduling may be perceived as adaptable by 
irrigation district planners (Burt and Lord 1981). 1 Irrigators may depend on private ditch and canal companies rather than the Bureau of Reclamation for surface water supplies. The Bureau of Reclamation has installed some pressure pipe systems to allow individual farmers to precisely control water delivered to their property. The largest system to be pressurized in this manner is in the Yakima area of Washington and will encompass 27,000 acres when it is completed. 2 Some delivery systems may require at least a day's notice to adapt to changes in demand, while in others, farm water deliveries are scheduled periodically. ${ }^{3}$ Capacity at times of peak demand, especially in arid regions, may also limit water delivery on demand. ${ }^{4}$

Despite the problems associated with operating surface water delivery systems, there does not seem to be sufficient justification to exclude acres from the analysis of improved scheduling energy-savings potential because of inflexibility in surface water delivery timing and amounts. No acres have been identified that, for these reasons alone, could not benefit to some extent from improved scheduing. 4

The full benefits of scheduling might not be realized if a system is underdesigned so that water supplies are frequently limited (Larson 1981). However, at least one empirical study fails to provide conclusive evidence that low well yields significantly reduce the likelihood of a farmer's use of scheduling (Rosenberg et al. 1983). Recomnendations based on complex scheduling methods normally will not differ significantly from continuous irrigation during intervals when evapotranspiration requirements are at their peak. As long as there are some periods when well yields exceed

1 Also, personal communication with Joe Lord, private irrigation scheduling consultant, Fresno, California, February 1984.

2 Personal communication with Dan Yribar, Bureau of Reclamation, Boise, Idaho, February 1984.

3 Personal communication with Monte McVay, Conservation Agronomist, Bureau of Reclamation, Boise, Idaho, February 1984.

4 Personal communication with Mike Stuber, Bureau of Reclamation Lower Columbia region, Boulder City, Nevada. 
evapotranspiration requirements, improved scheduling can lead to water savings. It is believed that most irrigators using ground water in the Pacific Northwest experience at least some periods during the spring and fall when low well yields are not a limiting factor. Thus, no acres were excluded from the analysis on the basis of low well yields.

\subsubsection{Technical Limits Due to Irrigation System}

Gravity flow acres are excluded from the analysis of potential energy savings through improved scheduling. Irrigators who use gravity flow methods have little control over the amounts of water applications necessary to meet water requirements at the bottom of a field. It is also difficult to control the duration of gravity flow irrigation sets. Modifications to gravity flow systems to reduce water usage are technically feasible (Green 1982) ${ }^{5}$ but entail additional labor costs that can be justified by energy savings oniy when water is pumped from deep wells. Except for some farmers in southern Idaho, gravicy flow irrigators in the Pacific Northwest use surface water and are unlikely to modify their systems solely on the basis of energy savings.

\subsubsection{Technical Limits Because of Crop Management Practices}

Consumptive use of water is only one factor among several influencing a farm manager's planning. For instance, farmers may sometimes run sprinklers more to apply fertilizer than to water crops. ${ }^{6}$ Harvesting practices may preclude irrigation at certain times; for example, alfalfa should not be irrigated when it will be cut within 4 to 6 days, nor can it be watered again until the hay is removed from the field (Sprinkler Irrigation Association 1975). Pesticide applications can often interfere with the use of optimal scheduling practices, especially on orchard crops. Although these and other factors may hinder the precise following of improved scheduing

\footnotetext{
5 Also, personal communication with Joe Lord, private irrigation scheduling consultant, Fresno, California, February 1984.

6 Personal communication with Mike Stuber, Bureau of Reclamation Lower Columbia region, Boulder City, Nevada.
} 
recommendations, they do not seem to imply that the water savings benefits of improved scheduling should be completely limited. Thus, no technical limits are applied to existing sprinkler acres on the basis of crop management considerations.

\subsection{CONSERVATION ALREADY ACHIEVED}

Variation in the types of available irrigation scheduling programs and a lack of primary data cause the development of estimates of acres in the Pacific Northwest on which improved irrigation is already being used to be difficult. One should not infer that because a farmer has implemented some form of irrigation scheduling, no further improvements are possible. It is believed that the use and knowledge of the type of improved irrigation scheduling practiced by private irrigation consultants is not widespread in the Pacific Northwest. However, little primary data on conservation achieved could be collected for this analysis, and only limited information is available from secondary sources.

Although a lack of data and resources precludes rigorous estimation of the acres on which improved irrigation scheduling is already being used, it is believed that it is inappropriate to assume that the usage level is zero. Available studies and personal interviews indicate that improved irrigation scheduling is being used by some farmers in the region. The available studies also indicate that complex scheduling methods are more likely to be found on water-sensitive and high-value crops, and are more often used by center-pivot irrigators than by irrigators using other sprinkler systems. Despite economic criteria that suggest a greater probability of finding scheduling where water is pumped from wells than where surface water is used, there seems to be no empirical basis for allocating conservation achieved based on water source.

Center-pivot acres seem to be about twice as likely to be scheduled as other sprinkler acres (Merchant and Herman 1984, Rosenberg et al. 1983). A survey of irrigators in north-central Oregon and southern Idaho (subregions 6 and 10) by Merchant and Herman found scheduling among 43 percent of centerpivot farmers and 20 percent of other farmers. As an additional proxy for farmer awareness of improved irrigation scheduling, a regional division will be 
made showing greater conservation achieved among farmers in the Columbia Basin, north-central Oregon and southern Idaho (subregions 3,6 and 10).

Scheduling seems to be a more common water management practice on potatoes, orchards and a few other high-value or water-sensitive crops than on other crops. The shape and size of potato tubers are very sensitive to soil moisture stress, and one study found scheduling used by half of the potato growers surveyed in the Burley, Idaho area (Merchant and Herman 1984). Sugar beets in the Burley area are also scheduled more often than other crops. Wheat, hay, corn, and pasture were rarely scheduled, even in a region where awareness of systematic scheduling methods was widespread (Merchant and Herman 1984). Although a survey in Nebraska concluded that corn was the crop most likely to be scheduled, it is believed that these results were as likely to be influenced by irrigation system as by crop, since corn was overwhelmingly more likely to be under center-pivot irrigation than were other crops (Rosenberg et al. 1983). Strawberries, grapes and orchards may be scheduled according to complex methods more frequently than other crops, in areas where they are grown (Merchant and Herman 1984). ${ }^{7}$ No additional distinctions between conservation achieved by crop are supported by available studies.

The percentages of irrigated acres which, for modeling purposes, were chosen to represent conservation achieved are shown in Tables 5.1 and 5.2. These percentages imply conservation achieved on the acres shown in Tables 5.3 , $5.4,5.5$ and 5.6. The estimates in the tables, based on interpretation of available information, can only approximate what primary data collection could reveal. The criteria for the numbers chosen were estimated differences in conservation achieved between regions, crops and irrigation systems, as discussed in this section.

7 Also, personal communication with Eric Scott, Motorola Inc., Fresno, California, February 1984. 
TABLE 5.1. Model Input Assumptions: Conservation Achieved On Center-Pivot Acres (\% of total 1984 acres)

Crop

\begin{tabular}{|c|c|c|c|c|c|c|}
\hline Region & Wheat & Alfalfa & Potatoes & Corn & Orchard & 0ther \\
\hline 1 & 0 & 0 & 20 & 15 & $\mathrm{NA}(\mathrm{a})$ & 10 \\
\hline 2 & 0 & 0 & 20 & 15 & NA & 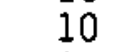 \\
\hline 3 & 5 & 5 & 40 & 25 & NA & 20 \\
\hline 4 & 0 & 0 & 20 & 15 & NA & 10 \\
\hline 5 & 0 & 0 & 20 & 15 & NA & 10 \\
\hline 6 & 5 & 5 & 40 & 25 & $N A$ & 20 \\
\hline 7 & 0 & 0 & 20 & 15 & NA & 10 \\
\hline 8 & 0 & 0 & 20 & 15 & NA & 10 \\
\hline$a$ & 0 & 0 & 20 & 15 & NA & 10 \\
\hline 10 & 5 & 5 & 50 & 25 & NA & 30 \\
\hline 11 & 0 & 0 & 20 & 15 & NA & 0 \\
\hline
\end{tabular}

(a) $N A=$ Not Applicable because of the small number of orchard acreages irrigated with center pivots.

TABLE 5.2. Model Input Assumptions: Conservation Achieved On Other Sprinkler Acres ( $\%$ of total 1984 acres)

Crop

Region Wheat Alfalfa Potatoes Corn Orchard other

$\begin{array}{rrrrrrr}1 & 0 & 0 & 10 & 5 & 15 & 5 \\ 2 & 0 & 0 & 10 & 5 & 15 & 5 \\ 3 & 5 & 5 & 20 & 10 & 30 & 10 \\ 4 & 0 & 0 & 10 & 5 & 15 & 5 \\ 5 & 0 & 0 & 10 & 5 & 15 & 5 \\ 6 & 5 & 5 & 20 & 10 & 30 & 10 \\ 7 & 0 & 0 & 10 & 5 & 15 & 5 \\ 8 & 0 & 0 & 10 & 5 & 15 & 5 \\ 9 & 0 & 0 & 10 & 5 & 15 & 5 \\ 10 & 5 & 5 & 25 & 10 & 30 & 15 \\ 11 & 0 & 0 & 10 & 5 & 15 & 5\end{array}$


TABLE 5.3. Model Input Assumptions: Conservation Achieved On Groundwater Center-Pivot Acres (Acres)

Crop

$\begin{array}{rrrrrrr}\text { Region } & \text { Wheat } & \text { Alfalfa } & \text { Potatoes } & \text { Corn } & \text { Orchard } & \text { Other } \\ 1 & 0 & 0 & 0 & 0 & 0 & 0 \\ 2 & 0 & 0 & 40 & 520 & 0 & 150 \\ 3 & 3,270 & 2,210 & 10,245 & 5,460 & 0 & 880 \\ 4 & 0 & 0 & 0 & 0 & 0 & 0 \\ 5 & 0 & 0 & 0 & 50 & 0 & 0 \\ 6 & 450 & 370 & 2,755 & 285 & 0 & 0 \\ 7 & 0 & 0 & 60 & 0 & 0 & 0 \\ 8 & 0 & 0 & 240 & 10 & 0 & 0 \\ 9 & 0 & 0 & 0 & 0 & 0 & 0 \\ 10 & 2,725 & 2,630 & 10,800 & 1,045 & 0 & 9,810 \\ 11 & 0 & 0 & 0 & 0 & 0 & 0\end{array}$

TABLE 5.4. Mode1 Input Assumptions: Conservation Achieved On Surface Water Center-Pivot Acres (Acres)

Crop

\begin{tabular}{rrrrrrr} 
Region & Wheat & Alfalfa & Potatoes & Corn & Orchard & Other \\
\cline { 3 - 5 } 1 & 0 & 0 & 0 & 0 & 0 & 0 \\
2 & 0 & 0 & 225 & 2,830 & 0 & 360 \\
3 & 3,860 & 2,805 & 21,845 & 13,170 & 0 & 6,620 \\
4 & 0 & 0 & 0 & 0 & 0 & 0 \\
5 & 0 & 0 & 15 & 285 & 0 & 0 \\
6 & 1,815 & 870 & 7,855 & 1,080 & 0 & 0 \\
7 & 0 & 0 & 220 & 0 & 0 & 0 \\
8 & 0 & 0 & 360 & 0 & 0 & 700 \\
9 & 0 & 0 & 0 & 275 & 0 & 15 \\
10 & 870 & 650 & 3,190 & 0 & 0 &
\end{tabular}


TABLE 5.5. Mode] Input Assumptions: Conservation Achieved On Groundwater Other Sprinkler Acres (Acres)

Crop

$\begin{array}{rrrrrrr}\text { Region } & \text { Wheat } & \text { Alfalfa } & \text { Potatoes } & \text { Corn } & \text { Orchard } & \text { Other } \\ 1 & 0 & 0 & 130 & 180 & 360 & 175 \\ 2 & 0 & 0 & 0 & 0 & 1,835 & 255 \\ 3 & 285 & 625 & 270 & 0 & 2,020 & 4,460 \\ 4 & 0 & 0 & 0 & 5 & 1,415 & 620 \\ 5 & 0 & 0 & 20 & 555 & 865 & 1,215 \\ 6 & 220 & 300 & 75 & 0 & 1,415 & 380 \\ 7 & 0 & 0 & 180 & 0 & 10 & 315 \\ 8 & 0 & 0 & 70 & 0 & 520 & 320 \\ 9 & 0 & 0 & 250 & 5 & 50 & 255 \\ 10 & 16,740 & 12,855 & 28,350 & 0 & 18,210 & 17,390 \\ 11 & 0 & 0 & 15 & 5 & 5 & 5\end{array}$

TABLE 5.6. Mode1 Input Assumptions: Conservation Achieved On Surface Water Other Sprinkler Acres (Acres)

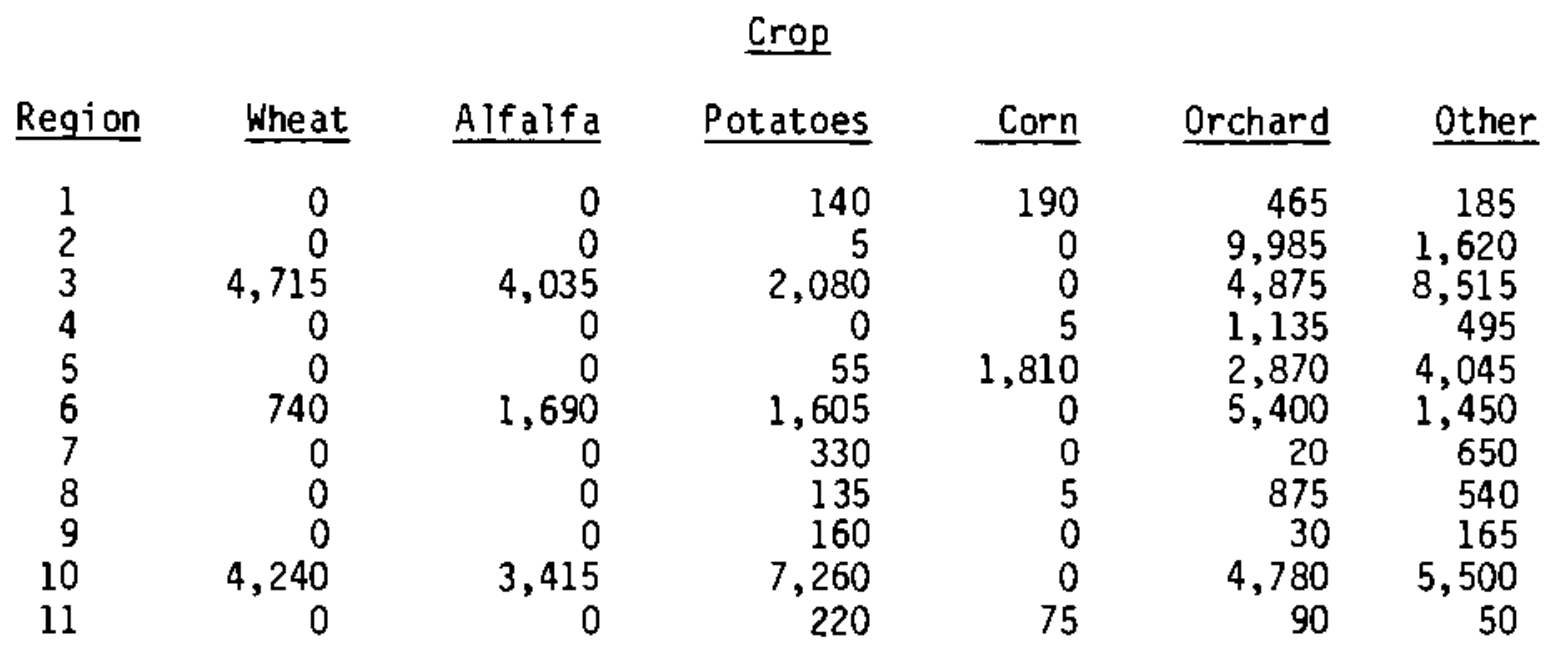




\subsection{ESTIMATION OF RESULTS}

As stated in the introduction of this report, the primary objective of this study is to develop cost and energy savings information on improved irrigation scheduling that BPA can use in its conservation program planning efforts. In this chapter, a brief discussion of the methodology used in this study, and the results derived using this methodology are presented.

\subsection{STUDY METHODOLOGY}

To facilitate understanding of the results of this study, a brief discussion of the methodology employed in deriving the study results is presented. Those wishing further detail on the computer model used in the estimation procedure should refer to other documents to be generated during this research effort.

In general, the kWh electrical energy use of an irrigation system can be estimated using the following equation:

$$
E=\frac{V \times H \times 1.024}{P P E}
$$

where $E$ = annual electrical energy use per acre in kWh for an irrigation system

$V=$ volume of water applied annually through the irrigation system in acre feet

$H=$ total dynamic head of the irrigation system in feet

$P P E=$ efficiency of the pumping plant in converting energy input into energy output

The way in which systematic irrigation scheduling reduces irrigation system energy use is by reducing the amount of water ( $V$ ) applied to the crop. The difference in energy use for improved irrigation scheduling is calculated by the following:

$$
\Delta E=\frac{V_{0} \times H \times 1.024}{P P E}-\frac{V_{1} \times H \times 1.024}{P P E}
$$


where $\Delta E=$ difference in annual energy use per acre in kWh between an irrigation system with improved scheduling and a system without improved scheduling

$v_{0}=$ total volume of water applied by an irrigation system without improved scheduling

$v_{1}=$ total volume of water applied by an irrigation system with improved scheduling

As noted in Chapter 3, all energy savings estimates developed in this study are based on the assumption that the conservation measures of lowpressure conversion and properly designed mainlines and fittings had been implemented prior to the use of improved irrigation scheduling. Thus, all of the energy savings estimates developed using the above equation are based upon total dynamic head (H) estimates that would likely be obtained after lowpressure conversion and proper design of mainline and fittings have been implemented.

To determine a cost per kWh saved using annual energy savings as the denominator, all costs must be converted to an annual equivalent or levelized cost basis. The equation used in this study for estimating the differences between the levelized costs of improved versus traditional irrigation scheduling was the following:

$$
\begin{aligned}
\triangle L E V & =L E V_{1}-L E V_{0} \\
& =O M_{1}-O M_{0}
\end{aligned}
$$

where $\triangle L E V=$ difference in the annual equivalent or levelized cost between improved irrigation scheduling $\left(L E V_{1}\right)$ and traditional irrigation scheduling (LEV 0 )

$O M_{1}=$ annual per-acre operation and maintenance costs for irrigating using improved irrigation scheduling

$O M_{0}=$ annual per-acre operation and maintenance costs for irrigating using traditional irrigation scheduling

Note that because of the assumption that the costs of improved irrigation scheduling are allocated using a per-acre charge, all costs of improved 
scheduling can be considered to be incremental operating and maintenance costs of performing irrigation.

Once the differences in annual $\mathrm{kWh}$ usage and annual levelized cost per acre are calculated, the cost per $k$ Wh saved is calculated by the following:

Cost per $k$ wh saved $=\frac{\Delta L E V}{\Delta E}$

The aggregate potential energy savings in average MW for improved scheduling are estimated by the following:

Potential savings in average $M W=\Delta E \times(A C E L-A C C A) / 1000 / 8760$

where ACEL = acres eligible to utilize improved irrigation scheduling (i.e., not limited by technical considerations)

$A C C A=$ acres that are already using improved irrigation scheduling

$1000,8760=$ factors for converting $k$ Wh savings to average MW of savings

6.2 COST PER KWH SAVED AND ENERGY-SAVINGS POTENTIAL FOR IMPROVED IRRIGATION SCHEDUL ING ON CENTER-PIVOT ACRES

Estimates of the average cost per kWh saved by subregion from using improved irrigation scheduling and the total potential energy savings that could be realized from such usage on existing and new center-pivot water sensitive crop acres are presented in Table 6.1. Note from these results that the potential energy savings and the cost per $k$ Wh saved from improved irrigation scheduling vary significantly among subregions and by water source. These results arise from the fact that energy savings from improved irrigation scheduling are highly dependent upon the amount of water necessary to sustain crop yields in a given subregion and the amount of lift required to deliver water to the field level. Thus, the potential energy savings are higher and the costs per kWh saved are lower from using improved irrigation scheduling in subregion 3, which has an average groundwater pumping lift of 346 feet and relatively high water application volumes, than in subregions where pumping 
TABLE 6.1. Estimated Energy-Savings Potential in Average MW and Cost Per kWh Saved in 1984 Mills for Improved Scheduling on Existing and New Center-Pivot WaterSensitive Crop (a) Acres

\begin{tabular}{|c|c|c|c|c|c|c|c|c|c|c|c|c|c|}
\hline & $\begin{array}{l}\text { Water } \\
\text { Source }\end{array}$ & 1 & 2 & 3 & 4 & 5 & ubregic & 7 & 8 & 9 & 10 & 11 & $\begin{array}{c}\text { BPA } \\
\text { Service } \\
\text { Area } \\
\end{array}$ \\
\hline $\begin{array}{l}\text { Energy Savings } \\
\text { on Existing } \\
\text { Acres in } \\
1984 \text { (Ave. Mw) }\end{array}$ & $\begin{array}{l}\text { Surface } \\
\text { Ground } \\
\text { Total }\end{array}$ & $\begin{array}{l}\text { NCP } \\
\text { NCP } \\
\text { NCP }\end{array}$ & $\begin{array}{l}0.19 \\
0.33 \\
0.52\end{array}$ & $\begin{array}{l}0.84 \\
2.31 \\
3.15\end{array}$ & $\begin{array}{l}0.00 \\
0.00 \\
0.00\end{array}$ & $\begin{array}{l}0.01 \\
0.00 \\
0.01\end{array}$ & $\begin{array}{l}0.36 \\
0.22 \\
0.58\end{array}$ & $\begin{array}{l}0.01 \\
0.00 \\
0.01\end{array}$ & $\begin{array}{l}0.02 \\
0.03 \\
0.05\end{array}$ & $\begin{array}{l}0.00 \\
0.00 \\
0.00\end{array}$ & $\begin{array}{l}0.41 \\
1.99 \\
2.40\end{array}$ & $\begin{array}{l}0.00 \\
0.00 \\
0.00\end{array}$ & $\begin{array}{l}1.84 \\
4.88 \\
6.72\end{array}$ \\
\hline $\begin{array}{l}\text { Cost Per kWh } \\
\text { Saved on Exist- } \\
\text { ing Acres } \\
\text { (1984 Mills) }\end{array}$ & $\begin{array}{l}\text { Surface } \\
\text { Ground } \\
\text { Average }\end{array}$ & $\begin{array}{l}\text { NCP } \\
\text { NCP } \\
\text { NCP }\end{array}$ & $\begin{array}{l}65.75 \\
26.05 \\
40.50\end{array}$ & $\begin{array}{l}61.78 \\
14.25 \\
26.96\end{array}$ & $\begin{array}{l}\text { NCP } \\
\text { NCP } \\
\text { NCP }\end{array}$ & $\begin{array}{r}149.50 \\
\text { NCP } \\
149.50\end{array}$ & $\begin{array}{l}23.88 \\
22.82 \\
23.48\end{array}$ & $\begin{array}{l}82.63 \\
45.00 \\
70.00\end{array}$ & $\begin{array}{l}96.70 \\
63.63 \\
74.68\end{array}$ & $\begin{array}{l}\text { NCP } \\
\text { NCP } \\
\text { NCP }\end{array}$ & $\begin{array}{l}74.69 \\
25.88 \\
34.25\end{array}$ & $\begin{array}{l}97.72 \\
51.38 \\
96.45\end{array}$ & $\begin{array}{l}58.43 \\
20.55 \\
30.92\end{array}$ \\
\hline $\begin{array}{l}\text { Energy Savings } \\
\text { on New Acres } \\
\text { in } 2003 \\
\text { (Ave. MW) }\end{array}$ & $\begin{array}{l}\text { Surface } \\
\text { Ground } \\
\text { Total }\end{array}$ & $\begin{array}{l}\text { NCP } \\
\text { NCP } \\
\text { NCP }\end{array}$ & $\begin{array}{l}0.00 \\
0.02 \\
0.02\end{array}$ & $\begin{array}{l}0.70 \\
0.00 \\
0.70\end{array}$ & $\begin{array}{l}0.00 \\
0.00 \\
0.00\end{array}$ & $\begin{array}{l}0.00 \\
0.00 \\
0.00\end{array}$ & $\begin{array}{l}0.05 \\
0.15 \\
0.20\end{array}$ & $\begin{array}{l}0.00 \\
0.00 \\
0.00\end{array}$ & $\begin{array}{l}0.00 \\
0.02 \\
0.02\end{array}$ & $\begin{array}{l}0.00 \\
0.00 \\
0.00\end{array}$ & $\begin{array}{l}0.06 \\
0.33 \\
0.39\end{array}$ & $\begin{array}{l}0.00 \\
0.00 \\
0.00\end{array}$ & $\begin{array}{l}0.81 \\
0.52 \\
1.33\end{array}$ \\
\hline $\begin{array}{l}\text { Cost Per kWh } \\
\text { Saved on New } \\
\text { Acres } \\
\text { (1984 Mills) }\end{array}$ & $\begin{array}{l}\text { Surface } \\
\text { Ground } \\
\text { Average }\end{array}$ & $\begin{array}{l}\text { NCP } \\
\text { NCP } \\
\text { NCP }\end{array}$ & $\begin{array}{r}\text { NCP } \\
26.05 \\
26.05\end{array}$ & $\begin{array}{r}62.90 \\
\text { NCP } \\
62.90\end{array}$ & $\begin{array}{l}\text { NCP } \\
\text { NCP } \\
\text { NCP }\end{array}$ & $\begin{array}{l}\text { NCP } \\
\text { NCP } \\
\text { NCP }\end{array}$ & $\begin{array}{l}24.29 \\
23.01 \\
23.32\end{array}$ & $\begin{array}{r}\text { NCP } \\
44.99 \\
44.99\end{array}$ & $\begin{array}{r}\text { NCP } \\
64.31 \\
64.31\end{array}$ & $\begin{array}{l}\text { NCP } \\
\text { NCP } \\
\text { NCP }\end{array}$ & $\begin{array}{l}75.50 \\
26.48 \\
34.44\end{array}$ & $\begin{array}{r}\text { NCP } \\
51.74 \\
51.74\end{array}$ & $\begin{array}{l}61.55 \\
26.59 \\
47.92\end{array}$ \\
\hline
\end{tabular}

(a) For purposes of this study, water-sensitive crops are defined as potatoes, corn and other miscellaneous crops. 
lifts and water application volumes are less. Of course, the aggregate energysavings potential on center-pivot acres in a subregion is also influenced by the number of center-pivot irrigation systems in use in the subregion.

The results shown in Table 6.1 illustrate that it will be necessary to target specific areas and farming operations if the potential energy savings from improved irrigation scheduling are to be obtained in a cost-effective manner. Improved irrigation scheduling at six dollars per acre will normaliy cost less than 25 mills per kwh saved on groundwater acres, while the cost will generally exceed 60 mills per $k$ wh saved on surface water acres. Note that an exception to the high cost of improved scheduling on surface water acres was found for north-central 0regon (subregion 6), where the surface water used in irrigation is lifted a substantial distance from its source.

Estimates of the cumulative energy savings in 5-mill increments of cost per kWh saved for improved scheduling costing six dollars per acre on centerpivot water-sensitive crop acres are shown in Table 6.2. The estimates presented in Table 6.2 reveal that a high proportion of the energy savings from improved scheduling can be obtained for a reasonable cost if careful targeting of the scheduling efforts is undertaken.

Almost 80 percent of the total aggregate energy savings available from improved irrigation scheduling on existing center-pivot water-sensitive crop acres can be obtained for a cost of less than $30 \mathrm{mill}$ s per $k$ Wh saved. In general, on any irrigation pumping installation having more than 190 feet of pumping $1 \mathrm{ift}$ in the major irrigation regions (Subregions 2, 3, 4, 6 and 10) energy savings could be obtained for a cost of less than 25 mills per kwh saved. Because such installations consume a high percentage of the total energy used in irrigation, using improved scheduling to obtain energy savings is less costly than a simple examination of the numbers presented in Table 6.1 would indicate.

Estimates presented in Table 6.3 illustrate that the cost effectiveness of improved scheduling on the new center-pivot water-sensitive crop acres that are forecast to come into existence in the next 20 years is significantly less than for existing acres. For example, only 3 percent of the total potential energy savings on new center-pivot water-sensitive crop acres are estimated to be available for 20 mills per $k$ hh saved or less. This result can be attributed 
IABLE 6.2. Estimated Cumulative Energy-Savings Potential (Ave. MW) in 5-Mill Increments of Cost Per kWh \{aved for Improved Scheduling on Existing Center-Pivot WaterSensitive Crop $(a)$ Acres

or

\begin{tabular}{|c|c|c|c|c|c|c|c|c|c|c|c|}
\hline \multirow[b]{2}{*}{ Year } & \multirow[b]{2}{*}{ Water Source } & \multicolumn{10}{|c|}{ Cost Per kWh Saved } \\
\hline & & 5 & 10 & 15 & 20 & 25 & 30 & 35 & 40 & 45 & 50 \\
\hline \multirow[t]{3}{*}{1984} & Surface Water & 0.00 & 0.00 & 0.00 & 0.11 & 0.11 & 0.36 & 0.36 & 0.36 & 0.36 & 0.36 \\
\hline & Groundwater & 0.00 & 0.00 & 0.00 & 2.35 & 4.05 & 4.63 & 5.85 & 4.85 & 4.85 & 4.85 \\
\hline & Total & 0.00 & 0.00 & 1.38 & 2.46 & 4.16 & 5.21 & 5.21 & 5.21 & 5.21 & 5.21 \\
\hline
\end{tabular}

Cost Per kWh Saved

(a) For purposes of this study, water-sensitive crops are defined as potatoes, corn and other miscellaneous crops. 
primarily to the fact that most of the new irrigated acres that are forecast to come into existence in the next 20 years are surface water acres with low pumping lifts, and thus, the costs per kWh saved for improved scheduling on new acres are increased.

\section{TABLE 6.3. Estimated Cumulative Energy-Savings \\ Potential (Ave. MW) in 5-Mill \\ Increments of Cost per kWh Saved \\ for Improved Scheduling on \\ New Genter-Pivot Water-Sensitive \\ Crop $(d)$ Acres}

\section{Cost per kWh Saved}

\begin{tabular}{|c|c|c|c|c|c|c|c|c|c|c|c|}
\hline ear & 0 & 5 & 10 & 15 & 20 & 25 & 30 & 35 & 40 & 45 & 50 \\
\hline 08 & 0.00 & 0.00 & 0.00 & 0.00 & 0.00 & 0.05 & 0.06 & 0.07 & 0.07 & 0.07 & 0.07 \\
\hline 1986 & 0.00 & 0.00 & 0.00 & 0.00 & 0.01 & 0.09 & 0.10 & 0.12 & 0.12 & 0.12 & 0.12 \\
\hline 1987 & 0.00 & 0.00 & 0.00 & 0.00 & 0.01 & 0.13 & 0.15 & 0.17 & 0.17 & 0.17 & 0.17 \\
\hline 1988 & 0.00 & 0.00 & 0.00 & 0.00 & 0.01 & 0.17 & 0.20 & 0.23 & 0.23 & 0.23 & 0.23 \\
\hline 1989 & 0.00 & 0.00 & 0.00 & 0.00 & 0.02 & 0.21 & 0.25 & 0.28 & 0.28 & 0.28 & 0.28 \\
\hline 1990 & 0.00 & 0.00 & 0.00 & 0.00 & 0.02 & 0.23 & 0.27 & 0.30 & 0.30 & 0.30 & 0.30 \\
\hline 1991 & 0.00 & 0.00 & 0.00 & 0.00 & 0.02 & 0.24 & 0.28 & 0.32 & 0.32 & 0.32 & 0.32 \\
\hline 1992 & 0.00 & 0.00 & 0.00 & 0.00 & 0.02 & 0.25 & 0.30 & 0.34 & 0.34 & 0.34 & 34 \\
\hline 199 & 0.00 & 0.00 & 0.00 & 0.00 & 0.02 & 0.26 & 0.32 & 0.36 & 0.36 & 0.36 & 36 \\
\hline 199 & 0.00 & 0.00 & 0.00 & 0.00 & 0.02 & 0.27 & 0.33 & 0.37 & 0.37 & 37 & 37 \\
\hline 199 & 0.00 & 0.00 & 0.00 & 0.00 & 0.03 & 0.29 & 0.34 & 0.38 & 0.38 & 0.38 & \\
\hline 199 & 0.00 & 0.00 & 0.00 & 0.00 & 0.04 & 0.30 & 0.37 & 0.41 & 0.41 & 0.41 & .41 \\
\hline 199 & 0.00 & 0.00 & 0.00 & 0.00 & 0.04 & 0.31 & 0.38 & 0.42 & 0.42 & 0.42 & 0.42 \\
\hline 199 & 0.00 & 0.00 & 0.00 & 0.00 & 0.04 & 0.32 & 0.39 & 0.44 & 0.44 & 0.44 & 4 \\
\hline 199 & 0.00 & 0.00 & 0.00 & 0.00 & 0.04 & 0.34 & 0.42 & 0.47 & 0.47 & 0.47 & 0.47 \\
\hline 200 & 0.00 & 0.00 & 0.00 & 0.00 & 0.04 & 0.35 & 0.44 & 0.50 & 0.50 & 0.50 & 0.50 \\
\hline & 0.00 & 0.00 & 0.00 & 0.00 & 0.04 & 0.36 & 0.46 & 0.52 & & & \\
\hline & 0.0 & 0.00 & 0.00 & 0.00 & 0.04 & 0.37 & 0.48 & & & & \\
\hline & 0.0 & 0. & 0.00 & 0.00 & 0.04 & 0.38 & 0.49 & 0 & 5 & 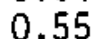 & \\
\hline
\end{tabular}

(a) For purposes of this study, water-sensitive crops are defined as potatoes, corn, and other miscellaneous crops.

Estimates of the average costs per $\mathrm{kWh}$ saved and the total potential energy savings by subregion for improved scheduling on existing and new centerpivot non-water-sensitive crop acres are presented in Table 6.4. The differences in cost per $\mathrm{kWh}$ saved between water-sensitive and non-watersensitive crop acres for improved scheduling are generally insignificant. 
TABLE 6.4. Estimated Energy-Savings Potential in Average MW and Cost Per kWh Saved in 1984 Mills for Improved Scheduling on Existing and New Center-Pivot Non-WaterSensitive Crop (a) Acres

\begin{tabular}{|c|c|c|c|c|c|c|c|c|c|c|c|c|c|}
\hline & $\begin{array}{r}\text { Water } \\
\text { Source }\end{array}$ & 1 & 2 & 3 & 4 & 5 & $\begin{array}{c}\text { dbregic } \\
6 \\
\end{array}$ & 7 & 8 & 9 & 10 & 11 & $\begin{array}{c}\text { BPA } \\
\text { Service } \\
\text { Area }\end{array}$ \\
\hline $\begin{array}{l}\text { Energy Savings } \\
\text { on Existing } \\
\text { Acres in } \\
1984 \text { (Ave. MW) }\end{array}$ & $\begin{array}{l}\text { Surface } \\
\text { Ground } \\
\text { Total }\end{array}$ & $\begin{array}{l}\text { NCP } \\
\text { NCP } \\
\text { NCP }\end{array}$ & $\begin{array}{l}0.19 \\
0.74 \\
0.93\end{array}$ & $\begin{array}{l}1.36 \\
6.39 \\
7.75\end{array}$ & $\begin{array}{l}0.17 \\
0.21 \\
0.38\end{array}$ & $\begin{array}{l}0.01 \\
0.01 \\
0.02\end{array}$ & $\begin{array}{l}1.27 \\
0.64 \\
1.91\end{array}$ & $\begin{array}{l}0.11 \\
0.54 \\
0.65\end{array}$ & $\begin{array}{l}0.13 \\
0.26 \\
0.39\end{array}$ & $\begin{array}{l}\text { NCP } \\
\text { NCP } \\
\text { NCP }\end{array}$ & $\begin{array}{l}0.56 \\
2.69 \\
3.25\end{array}$ & $\begin{array}{l}0.20 \\
0.01 \\
0.21\end{array}$ & $\begin{array}{r}4.00 \\
11.49 \\
15.49\end{array}$ \\
\hline $\begin{array}{l}\text { Cost Per kWh } \\
\text { Saved on Exist- } \\
\text { ing Acres } \\
(1984 \mathrm{Mi11s})\end{array}$ & $\begin{array}{l}\text { Surface } \\
\text { Ground } \\
\text { Average }\end{array}$ & $\begin{array}{l}\text { NCP } \\
\text { NCP } \\
\text { NCP }\end{array}$ & $\begin{array}{l}74.73 \\
27.03 \\
36.92\end{array}$ & $\begin{array}{l}64.72 \\
14.84 \\
23.57\end{array}$ & $\begin{array}{l}66.23 \\
27.32 \\
44.64\end{array}$ & $\begin{array}{r}114.03 \\
75.81 \\
98.43\end{array}$ & $\begin{array}{l}24.58 \\
21.51 \\
23.55\end{array}$ & $\begin{array}{l}67.55 \\
35.89 \\
41.26\end{array}$ & $\begin{array}{l}75.81 \\
58.00 \\
63.81\end{array}$ & $\begin{array}{l}\text { NCP } \\
\text { NCP } \\
\text { NCP }\end{array}$ & $\begin{array}{l}77.47 \\
26.72 \\
35.50\end{array}$ & $\begin{array}{l}88.05 \\
46.65 \\
87.04\end{array}$ & $\begin{array}{l}56.02 \\
21.03 \\
30.07\end{array}$ \\
\hline $\begin{array}{l}\text { Energy Savings } \\
\text { on New Acres } \\
\text { in } 2003 \\
\text { (Ave. MW) }\end{array}$ & $\begin{array}{l}\text { Surface } \\
\text { Ground } \\
\text { Total }\end{array}$ & $\begin{array}{l}\text { NCP } \\
\text { NCP } \\
\text { NCP }\end{array}$ & $\begin{array}{l}0.00 \\
0.05 \\
0.05\end{array}$ & $\begin{array}{l}0.82 \\
0.00 \\
0.82\end{array}$ & $\begin{array}{l}0.06 \\
0.02 \\
0.08\end{array}$ & $\begin{array}{l}0.00 \\
0.01 \\
0.01\end{array}$ & $\begin{array}{l}0.11 \\
0.34 \\
0.45\end{array}$ & $\begin{array}{l}0.00 \\
0.08 \\
0.08\end{array}$ & $\begin{array}{l}0.00 \\
0.11 \\
0.11\end{array}$ & $\begin{array}{l}0.00 \\
0.00 \\
0.00\end{array}$ & $\begin{array}{l}0.08 \\
0.40 \\
0.48\end{array}$ & $\begin{array}{l}0.00 \\
0.05 \\
0.05\end{array}$ & $\begin{array}{l}1.07 \\
1.06 \\
2.13\end{array}$ \\
\hline $\begin{array}{l}\text { Cost Per kWh } \\
\text { Saved on New } \\
\text { Acres } \\
\text { (1984 Mills) }\end{array}$ & $\begin{array}{l}\text { Surface } \\
\text { Ground } \\
\text { Average }\end{array}$ & $\begin{array}{l}\text { NCP } \\
N C P \\
N C P\end{array}$ & $\begin{array}{r}\text { NCP } \\
27.03 \\
27.03\end{array}$ & $\begin{array}{r}64.59 \\
\text { NCP } \\
64.59\end{array}$ & $\begin{array}{l}66.23 \\
27.32 \\
54.14\end{array}$ & $\begin{array}{r}N C P \\
75.81 \\
75.81\end{array}$ & $\begin{array}{l}24.58 \\
21.51 \\
22.56\end{array}$ & $\begin{array}{r}\text { NCP } \\
35.89 \\
35.89\end{array}$ & $\begin{array}{r}\text { NCP } \\
58.00 \\
58.00\end{array}$ & $\begin{array}{l}\text { NCP } \\
\text { NCP } \\
\text { NCP }\end{array}$ & $\begin{array}{l}77.47 \\
26.74 \\
35.36\end{array}$ & $\begin{array}{r}\text { NCP } \\
46.66 \\
46.66\end{array}$ & $\begin{array}{l}61.62 \\
30.33 \\
46.03\end{array}$ \\
\hline
\end{tabular}

(a) For purposes of this study, non-water-sensitive crops are defined as wheat, hay, orchard and other miscellaneous crops. 
However, costs per $k$ Wh saved do not account for the increased yields that are thought to be one of the primary benefits of using improved scheduling on watersensitive crop acres. The total potential energy savings of improved scheduling on non-water-sensitive crop acres are significantly larger than on water-sensitive crop acres because of the larger number of non-water-sensitive crop acres.

Results shown in Table 6.5 indicate that almost 70 percent of the total potential energy savings on existing center-pivot non-water-sensitive crop acres can be obtained for $30 \mathrm{mills}$ per $\mathrm{kWh}$ saved or less. Less than 20 percent of the total potential energy savings would cost more than 50 mills per $k$ Wh saved to acquire.

Estimates presented in Table 6.6 indicate again that improved scheduling on the new center-pivot acres that are forecast to come into existence in the next 20 years is less cost effective than improved scheduling on existing center-pivot acres. Only 12 percent of the total potential energy savings on new center-pivot non-water-sensitive crop acres are estimated to be obtainable for 20 mills per $k$ wh saved or less. Again, this result can be attributed to the preponderance of surface water acres in the new acres forecast to be developed by 2003 .

\subsection{COST PER KWH SAVED AND ENERGY-SAVINGS POTENTIAL FOR IMPROVED IRRIGATION SCHEDULING ON OTHER SPRINKLER ACRES}

Estimates of the average cost per $k$ Wh saved by subregion from using improved irrigation scheduling on existing other sprinkler water-sensitive crop acres and the potential energy savings that could result from such usage are presented in Table 6.7. The costs per kWh saved estimates for improved irrigation scheduling are significantly higher for other sprinkler systems than for center pivots primarily because improved scheduling is assumed to be less effective in reducing water use on other sprinkler acres. In addition, a higher proportion of other sprinkler acres are located in areas where water application volumes are relatively low.

Similar to center-pivot acres, variation occurs among subregions and by water source in the energy-savings potential and the cost per $k$ wh saved for using improved irrigation scheduling on other sprinkler acres. The 
TABLE 6.5. Estimated Cumulative Energy-Savings Potential (Ave. MW) in 5-Mill Increments of Cost Per kWh \{aved for Improved Scheduling on Existing Center-Pivot Non-WaterSensitive Crop (a) Acres

(a) For purposes of this study, non-water-sensitive crops are defined as wheat, hay, orchard, and other miscellaneous crops. 
TABLE 6.6. Estimated Cumulative Energy-Savings

Potential (Ave. MH) in 5-Mill

Increments of Cost per kWh Saved

for Improved Scheduling on

New Center-Pivot Non-Water-Sensitive

Crop acres

\section{Cost per kwh Saved}

$\begin{array}{llllllllllll}\text { Year } & 0 & 5 & 10 & 15 & 20 & 25 & 30 & 35 & 40 & 45 & 50 \\ 1985 & 0.00 & 0.00 & 0.00 & 0.00 & 0.03 & 0.05 & 0.08 & 0.10 & 0.10 & 0.10 & 0.10 \\ 1986 & 0.00 & 0.00 & 0.00 & 0.00 & 0.05 & 0.10 & 0.14 & 0.18 & 0.18 & 0.18 & 0.18 \\ 1987 & 0.00 & 0.00 & 0.00 & 0.00 & 0.07 & 0.14 & 0.22 & 0.27 & 0.27 & 0.27 & 0.27 \\ 1988 & 0.00 & 0.00 & 0.00 & 0.00 & 0.10 & 0.19 & 0.29 & 0.36 & 0.36 & 0.36 & 0.36 \\ 1989 & 0.00 & 0.00 & 0.00 & 0.00 & 0.12 & 0.23 & 0.35 & 0.44 & 0.44 & 0.44 & 0.44 \\ 1990 & 0.00 & 0.00 & 0.00 & 0.00 & 0.15 & 0.26 & 0.40 & 0.50 & 0.50 & 0.51 & 0.51 \\ 1991 & 0.00 & 0.00 & 0.00 & 0.00 & 0.16 & 0.28 & 0.44 & 0.55 & 0.55 & 0.55 & 0.56 \\ 1992 & 0.00 & 0.00 & 0.00 & 0.00 & 0.17 & 0.29 & 0.45 & 0.56 & 0.56 & 0.57 & 0.58 \\ 1993 & 0.00 & 0.00 & 0.00 & 0.00 & 0.17 & 0.31 & 0.47 & 0.60 & 0.60 & 0.62 & 0.62 \\ 1994 & 0.00 & 0.00 & 0.00 & 0.00 & 0.17 & 0.31 & 0.49 & 0.63 & 0.63 & 0.64 & 0.65 \\ 1995 & 0.00 & 0.00 & 0.00 & 0.00 & 0.18 & 0.33 & 0.52 & 0.67 & 0.67 & 0.68 & 0.69 \\ 1996 & 0.00 & 0.00 & 0.00 & 0.00 & 0.20 & 0.36 & 0.55 & 0.71 & 0.71 & 0.73 & 0.73 \\ 1997 & 0.00 & 0.00 & 0.00 & 0.00 & 0.20 & 0.36 & 0.56 & 0.73 & 0.73 & 0.75 & 0.76 \\ 1998 & 0.00 & 0.00 & 0.00 & 0.00 & 0.21 & 0.38 & 0.59 & 0.78 & 0.78 & 0.80 & 0.81 \\ 1999 & 0.00 & 0.00 & 0.00 & 0.00 & 0.23 & 0.41 & 0.63 & 0.83 & 0.83 & 0.85 & 0.86 \\ 2000 & 0.00 & 0.00 & 0.00 & 0.00 & 0.23 & 0.43 & 0.66 & 0.89 & 0.89 & 0.92 & 0.92 \\ 2001 & 0.00 & 0.00 & 0.00 & 0.00 & 0.23 & 0.44 & 0.70 & 0.93 & 0.93 & 0.97 & 0.98 \\ 2002 & 0.00 & 0.00 & 0.00 & 0.00 & 0.24 & 0.46 & 0.71 & 0.96 & 0.96 & 1.00 & 1.00 \\ 2003 & 0.00 & 0.00 & 0.00 & 0.00 & 0.25 & 0.48 & 0.74 & 0.99 & 0.99 & 1.04 & 1.05\end{array}$

(a) For purposes of this study, non-water-sensitive crops are defined as wheat, hay, orchard, and other miscellaneous crops. 
TABLE 6.7. Estimated Energy-Savings Potential in Average MW and Cost Per kWh Saved jn 1984 Mills for Improyed Scheduling on Existing and New Other Sprinkler (a) Water-Sensitive Crop $(b)$ Acres

\begin{tabular}{|c|c|c|c|c|c|c|c|c|c|c|c|c|c|}
\hline & $\begin{array}{l}\text { Water } \\
\text { Source }\end{array}$ & 1 & 2 & 3 & 4 & 5 & ubregic & 7 & 8 & 9 & 10 & 11 & $\begin{array}{c}8 P A \\
\text { Service } \\
\text { Area } \\
\end{array}$ \\
\hline $\begin{array}{l}\text { Energy Savings } \\
\text { on Existing } \\
\text { Acres in } \\
1984 \text { (Ave. MW) }\end{array}$ & $\begin{array}{l}\text { Surface } \\
\text { Ground } \\
\text { Total }\end{array}$ & $\begin{array}{l}0.01 \\
0.02 \\
0.03\end{array}$ & $\begin{array}{l}0.08 \\
0.12 \\
0.20\end{array}$ & $\begin{array}{l}0.08 \\
0.82 \\
0.90\end{array}$ & $\begin{array}{l}0.04 \\
0.11 \\
0.15\end{array}$ & $\begin{array}{l}0.25 \\
0.10 \\
0.35\end{array}$ & $\begin{array}{l}0.11 \\
0.06 \\
0.17\end{array}$ & $\begin{array}{l}0.06 \\
0.05 \\
0.11\end{array}$ & $\begin{array}{l}0.09 \\
0.02 \\
0.11\end{array}$ & $\begin{array}{l}0.02 \\
0.01 \\
0.03\end{array}$ & $\begin{array}{l}0.46 \\
1.67 \\
2.13\end{array}$ & $\begin{array}{l}0.02 \\
0.00 \\
0.02\end{array}$ & $\begin{array}{l}1.22 \\
2.98 \\
4.20\end{array}$ \\
\hline $\begin{array}{l}\text { Cost Per kWh } \\
\text { Saved on Exist- } \\
\text { ing Acres } \\
\text { (1984 Mills) }\end{array}$ & $\begin{array}{l}\text { Surface } \\
\text { Ground } \\
\text { Average }\end{array}$ & $\begin{array}{l}332.68 \\
272.27 \\
301.55\end{array}$ & $\begin{array}{r}104.12 \\
42.00 \\
70.46\end{array}$ & $\begin{array}{l}99.16 \\
23.47 \\
41.09\end{array}$ & $\begin{array}{l}85.05 \\
36.52 \\
48.96\end{array}$ & $\begin{array}{l}219.66 \\
174.82 \\
206.84\end{array}$ & $\begin{array}{l}31.87 \\
31.09 \\
31.64\end{array}$ & $\begin{array}{r}121.12 \\
67.63 \\
97.08\end{array}$ & $\begin{array}{l}150.92 \\
110.62 \\
144.59\end{array}$ & $\begin{array}{r}129.90 \\
67.37 \\
111.18\end{array}$ & $\begin{array}{r}139.71 \\
50.80 \\
70.29\end{array}$ & $\begin{array}{r}160.20 \\
86.17 \\
159.10\end{array}$ & $\begin{array}{r}133.87 \\
47.91 \\
76.14\end{array}$ \\
\hline $\begin{array}{l}\text { Energy Savings } \\
\text { on New Acres } \\
\text { in } 2003 \\
\text { (Ave. MW) }\end{array}$ & $\begin{array}{l}\text { Surface } \\
\text { Ground } \\
\text { Total }\end{array}$ & $\begin{array}{l}\text { NOS } \\
\text { NOS } \\
\text { NOS }\end{array}$ & $\begin{array}{l}0.18 \\
0.00 \\
0.18\end{array}$ & $\begin{array}{l}0.01 \\
0.01 \\
0.02\end{array}$ & $\begin{array}{l}0.00 \\
0.09 \\
0.09\end{array}$ & $\begin{array}{l}0.02 \\
0.03 \\
0.05\end{array}$ & $\begin{array}{l}0.00 \\
0.01 \\
0.01\end{array}$ & $\begin{array}{l}0.00 \\
0.01 \\
0.01\end{array}$ & $\begin{array}{l}0.00 \\
0.01 \\
0.01\end{array}$ & $\begin{array}{l}0.00 \\
0.01 \\
0.01\end{array}$ & $\begin{array}{l}0.07 \\
0.29 \\
0.36\end{array}$ & $\begin{array}{l}0.00 \\
0.00 \\
0.00\end{array}$ & $\begin{array}{l}0.28 \\
0.46 \\
0.74\end{array}$ \\
\hline $\begin{array}{l}\text { Cost Per kWh } \\
\text { Saved on New } \\
\text { Acres } \\
\text { (1984 Mills) }\end{array}$ & $\begin{array}{l}\text { Surface } \\
\text { Ground } \\
\text { Average }\end{array}$ & $\begin{array}{l}\text { NOS } \\
\text { NOS } \\
\text { NOS }\end{array}$ & $\begin{array}{r}\text { NOS } \\
42.00 \\
42.00\end{array}$ & $\begin{array}{r}103.33 \\
\text { NOS } \\
103.33\end{array}$ & $\begin{array}{l}85.05 \\
36.52 \\
59.59\end{array}$ & $\begin{array}{r}\text { NOS } \\
174.82 \\
174.82\end{array}$ & $\begin{array}{l}37.67 \\
31.21 \\
33.70\end{array}$ & $\begin{array}{r}\text { NOS } \\
67.78 \\
67.78\end{array}$ & $\begin{array}{r}\text { NOS } \\
110.78 \\
110.78\end{array}$ & $\begin{array}{r}\text { NOS } \\
67.73 \\
67.73\end{array}$ & $\begin{array}{r}139.91 \\
51.02 \\
67.87\end{array}$ & $\begin{array}{r}\text { NOS } \\
86.85 \\
86.85\end{array}$ & $\begin{array}{r}106.70 \\
75.61 \\
87.27\end{array}$ \\
\hline
\end{tabular}

(a) Other sprinkler irrigation systems are handmove, sideroll, and solid-set systems.

(D) For purposes of this study, water-sensitive crops are defined as potatoes, corn and other miscellaneous crops. 
applications with the highest energy-savings potential are groundwater acres in subregions 3 and 10 . The energy-savings potential on groundwater acres in subregion 10 is particularly significant, because it comprises over 55 percent of the total BPA service area energy savings from improved scheduling on other sprinkler water-sensitive crop acres. The lowest estimated costs per kwh saved were found for groundwater acres in subregions 3 and 6 .

The total potential energy savings that could result from using improved irrigation scheduling are small for other sprinkler water-sensitive crop acres because only a small number of such acres are irrigated with other sprinkler systems. In addition, results presented in Table 6.8 reveal that only 45 percent of the total potential savings for other sprinkier systems on watersensitive crop acres could be obtained for a cost of 50 mills per kwh saved or less. Results presented in Table 6.9 indicate that only 24 percent of the estimated potential energy savings on new other sprinkler water-sensitive crop acres can be obtained for $50 \mathrm{mills}$ per $\mathrm{kWh}$ saved or less.

Estimates of the average costs per $k$ Wh saved and the total potential energy savings by subregion for improved scheduling on existing and new other sprinkler non-water-sensitive crop acres are shown in Table 6.10. Because of the significantly larger number of non-water-sensitive crop acres irrigated with other sprinkier systems, the potential energy savings on these acres are more than five times larger than the potential savings on water-sensitive acres. However, the costs per kwh saved for obtaining these savings are again relatively high and are below 40 mills only in subregions with high pumping lifts and water application volumes.

Results presented in Table 6.11 demonstrate that only seven percent of the total potential energy savings for improved scheduling on other sprinkler nonwater-sensitive crop acres can be obtained for $30 \mathrm{mills}$ per kwh saved or less. Approximately 38 percent of the total potential savings on existing dcres can be obtained for $50 \mathrm{mill}$ s per $\mathrm{kWh}$ saved or less. Estimates presented in Table 6.12 indicate that only 29 percent of the total potential energy savings on new other sprinkier non-water-sensitive crop acres can be obtained for 50 milis per kWh saved or less. 
TABLE 6.8. Estimated Cumulative Energy-Savings Potential (Ave. MW) in 5-Mill Increments of Cost Per kWh Saved for Improved Scheduling on Existing Other Sprinkler (a) Water-Sensitive Crop (b) Acres

(a) Other sprinkler irrigation systems are handmove, sideroll, and solid-set systems.

(b) For purposes of this study, water-sensitive crops are defined as potatoes, corn, and other miscellaneous crops. 
TABLE 6.9. Estimated Cumulative Energy-Savings

Potential (Ave. MW) in 5-Mill

Increments of Cost per kWh Saved

for Improved Schedulipg on

New Other Spriakler Water-

Sensitive Crop ${ }^{(6)}$ Acres

Cost per kWh Saved

\begin{tabular}{|c|c|c|c|c|c|c|c|c|c|c|c|}
\hline ar & 0 & 5 & 10 & 15 & 20 & 25 & 30 & 35 & 40 & 45 & 50 \\
\hline 1085 & 0.00 & 0.00 & 0.00 & 0.00 & 0.00 & 0.00 & 0.00 & 0.00 & 0.00 & 0.00 & 0.02 \\
\hline & 00 & 0.00 & 0.00 & 0.00 & 0.00 & 0.00 & 0.01 & 0.01 & 0.01 & 0.01 & 0.03 \\
\hline 198 & 0.00 & 0.00 & 0.00 & 0.00 & 0.00 & 0.00 & 0.01 & 0.01 & 0.01 & 0.01 & 0.05 \\
\hline & 0.00 & 0.00 & 0.00 & 0.00 & 0.00 & 0.00 & 0.01 & 0.01 & 0.01 & 0.01 & 0.06 \\
\hline 989 & 0.00 & 0.00 & 0.00 & 0.00 & 0.00 & 0.00 & 0.02 & 0.02 & 0.02 & 0.02 & 0.08 \\
\hline & 0.00 & 0.00 & 0.00 & 0.00 & 0.00 & 0.00 & 0.02 & 0.02 & 0.02 & 0.02 & 0.09 \\
\hline 9 & 0.00 & 0.00 & 0.00 & 0.00 & 0.00 & 0.00 & 0.02 & 0.02 & 0.02 & 0.03 & 0.10 \\
\hline 19 & 0.00 & 0.00 & 0.00 & 0.00 & 0.00 & 0.00 & 0.0 & 0.02 & 0.02 & 0.03 & 0.10 \\
\hline 199 & 0.00 & 0.00 & 0.00 & 0.00 & 0.00 & 0.00 & 0.02 & 0.02 & 0.03 & 0.03 & 0.11 \\
\hline & 0.00 & 0.00 & 0.00 & 0.00 & 0.00 & 0.00 & 0.02 & 0.02 & & & \\
\hline 19 & 0.00 & 0.00 & 0.00 & 0.00 & 0.00 & 0.00 & 0.02 & 0.03 & 0.04 & 0.05 & 0.12 \\
\hline & 0.0 & 0.00 & 0.00 & 0.00 & 0.00 & 0.00 & 0.0 & & & & 0.13 \\
\hline & 0.0 & 0.00 & 0.00 & 0.00 & 0.00 & 0.00 & 0.02 & 0.03 & 0.04 & 0.05 & 0.13 \\
\hline 199 & 0. & 0.00 & 0.00 & 0.00 & 0.00 & 0.0 & 0. & 0.04 & 0.04 & 0. & 0.14 \\
\hline & 0.00 & 0.00 & 0.00 & 0.00 & 0.00 & 0.00 & 0.03 & 0.04 & 0.05 & 0.05 & 0.16 \\
\hline & 0.0 & 0.00 & 0.00 & 0.00 & 0.00 & 0.00 & 0.03 & 0.04 & 0.05 & 0.06 & 0.17 \\
\hline & 0.0 & 0.00 & 0.00 & 0.00 & 0.00 & 0.00 & 0.03 & 0.04 & 0.05 & 0.06 & 0.17 \\
\hline & 0. & 0.0 & 0.00 & 0.00 & 0. & 0.1 & 0.03 & 0.04 & 0. & 0.06 & 0.18 \\
\hline & 0.0 & .00 & .00 & 0.00 & 0.0 & 0.00 & 0.03 & 0.04 & 0.05 & 0.06 & - \\
\hline
\end{tabular}

(a) Other sprinkler irrigation systems are handmove, sideroll, and solidset systems.

(b) For purposes of this study, water-sensitive crops are defined as potatoes, corn and other miscellaneous crops. 
TABLE 6.10. Estimated Energy-Savings Potential in Average MW and Cost Per kWh Saved jn $1984 \mathrm{Mills}$ for Improved Spheduling on Existing and New Other Sprinkler (a) Non-Water-Sensitive Crop (b) Acres

\begin{tabular}{|c|c|c|c|c|c|c|c|c|c|c|c|c|c|}
\hline & $\begin{array}{c}\text { Water } \\
\text { Source }\end{array}$ & 1 & 2 & 3 & 4 & 5 & $\begin{array}{c}\text { ubregic } \\
6 \\
\end{array}$ & 7 & 8 & 9 & 10 & 11 & $\begin{array}{c}\text { 8PA } \\
\text { Service } \\
\text { Area } \\
\end{array}$ \\
\hline $\begin{array}{l}\text { Energy Savings } \\
\text { on Existing } \\
\text { Acres in } \\
1984 \text { (Ave. MW) }\end{array}$ & $\begin{array}{l}\text { Surface } \\
\text { Ground } \\
\text { Total }\end{array}$ & $\begin{array}{l}0.07 \\
0.08 \\
0.15\end{array}$ & $\begin{array}{l}0.75 \\
0.74 \\
1.49\end{array}$ & $\begin{array}{l}1.28 \\
1.58 \\
2.86\end{array}$ & $\begin{array}{l}0.25 \\
0.93 \\
1.18\end{array}$ & $\begin{array}{l}0.43 \\
0.17 \\
0.60\end{array}$ & $\begin{array}{l}1.14 \\
0.37 \\
1.51\end{array}$ & $\begin{array}{l}0.67 \\
0.28 \\
0.95\end{array}$ & $\begin{array}{l}0.83 \\
0.16 \\
0.99\end{array}$ & $\begin{array}{l}0.34 \\
0.20 \\
0.54\end{array}$ & $\begin{array}{r}1.89 \\
8.17 \\
10.06\end{array}$ & $\begin{array}{l}1.26 \\
0.03 \\
1.29\end{array}$ & $\begin{array}{r}8.91 \\
12.71 \\
21.62\end{array}$ \\
\hline $\begin{array}{l}\text { Cost Per kWh } \\
\text { Saved on Exist- } \\
\text { ing Acres } \\
\text { (1984 Mills) }\end{array}$ & $\begin{array}{l}\text { Surface } \\
\text { Ground } \\
\text { Average }\end{array}$ & $\begin{array}{l}327.62 \\
267.22 \\
295.71\end{array}$ & $\begin{array}{r}126.45 \\
53.19 \\
89.87\end{array}$ & $\begin{array}{r}109.95 \\
24.16 \\
62.56\end{array}$ & $\begin{array}{r}100.09 \\
43.89 \\
55.91\end{array}$ & $\begin{array}{l}204.64 \\
161.43 \\
192.43\end{array}$ & $\begin{array}{l}38.34 \\
37.01 \\
38.02\end{array}$ & $\begin{array}{r}110.02 \\
63.23 \\
96.23\end{array}$ & $\begin{array}{r}123.33 \\
97.33 \\
118.99\end{array}$ & $\begin{array}{r}128.74 \\
67.11 \\
106.13\end{array}$ & $\begin{array}{r}129.06 \\
46.79 \\
62.04\end{array}$ & $\begin{array}{r}147.12 \\
79.72 \\
145.52\end{array}$ & $\begin{array}{c}119.51 \\
48.18 \\
77.41\end{array}$ \\
\hline $\begin{array}{l}\text { Energy Savings } \\
\text { on New Acres } \\
\text { in } 2003 \\
\text { (Ave. MW) }\end{array}$ & $\begin{array}{l}\text { Surface } \\
\text { Ground } \\
\text { Total }\end{array}$ & $\begin{array}{l}\text { NOS } \\
\text { NOS } \\
\text { NOS }\end{array}$ & $\begin{array}{l}0.00 \\
0.05 \\
0.05\end{array}$ & $\begin{array}{l}0.76 \\
0.00 \\
0.76\end{array}$ & $\begin{array}{l}0.08 \\
0.11 \\
0.19\end{array}$ & $\begin{array}{l}0.00 \\
0.16 \\
0.16\end{array}$ & $\begin{array}{l}0.10 \\
0.20 \\
0.30\end{array}$ & $\begin{array}{l}0.00 \\
0.04 \\
0.04\end{array}$ & $\begin{array}{l}0.00 \\
0.07 \\
0.07\end{array}$ & $\begin{array}{l}0.00 \\
0.15 \\
0.15\end{array}$ & $\begin{array}{l}0.27 \\
1.22 \\
1.49\end{array}$ & $\begin{array}{l}0.00 \\
0.31 \\
0.31\end{array}$ & $\begin{array}{l}1.21 \\
2.31 \\
3.52\end{array}$ \\
\hline $\begin{array}{l}\text { Cost Per kWh } \\
\text { Saved on New } \\
\text { Acres } \\
\text { (1984 Mills) }\end{array}$ & $\begin{array}{l}\text { Surface } \\
\text { Ground } \\
\text { Average }\end{array}$ & $\begin{array}{l}\text { NOS } \\
\text { NOS } \\
\text { NOS }\end{array}$ & $\begin{array}{r}\text { NOS } \\
53.48 \\
53.48\end{array}$ & $\begin{array}{r}109.84 \\
\text { NOS } \\
109.84\end{array}$ & $\begin{array}{r}100.09 \\
44.10 \\
67.82\end{array}$ & $\begin{array}{r}\text { NOS } \\
163.02 \\
163.02\end{array}$ & $\begin{array}{l}38.50 \\
37.50 \\
37.82\end{array}$ & $\begin{array}{r}\text { NOS } \\
63.24 \\
63.24\end{array}$ & $\begin{array}{r}\text { NOS } \\
97.50 \\
97.50\end{array}$ & $\begin{array}{r}\text { NOS } \\
67.12 \\
67.12\end{array}$ & $\begin{array}{r}129.06 \\
46.90 \\
61.85\end{array}$ & $\begin{array}{r}\text { NOS } \\
79.76 \\
79.76\end{array}$ & $\begin{array}{r}107.86 \\
61.59 \\
77.42\end{array}$ \\
\hline
\end{tabular}

(a) 0ther sprinkler irrigation systems are handmove, sideroll, and solid-set systems.

(b) For purposes of this study, non-water-sensitive crops are defined as wheat, hay, orchard and other miscellaneous crops. 
TABLE 6.11. Estimated Cumulative Energy-Savings Potential (Ave. MW) in 5-Mill Increments of Cost Per kWh Saved for Improved Scheduling on Existing Other Sprinkler (a) Non-Water-Sensitive Crop (b) Acres

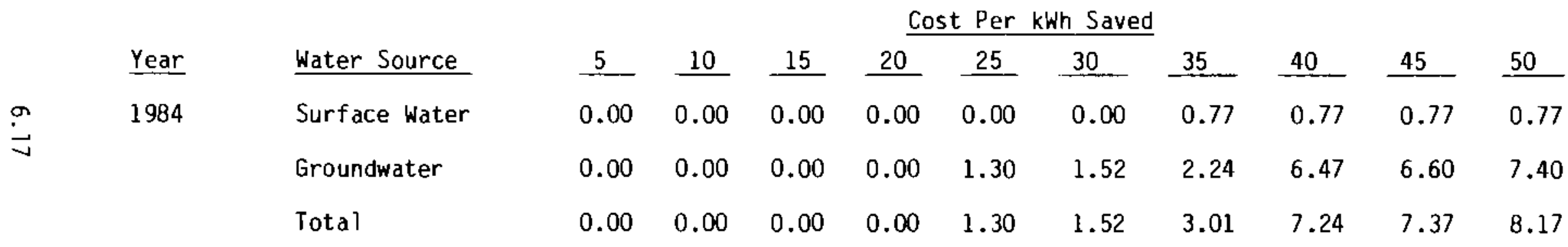

(a) Other sprinkler irrigation systems are handmove, sideroll, and solid-set systems.

(b) For purposes of this study, non-water-sensitive crops are defined as wheat, hay, orchard and other miscellaneous crops. 
TABLE 6.12. Estimated Cumulative Energy-Savings

Potential (Ave. MW) in 5-Mill

Increments of Cost per kWh Saved

for Improved Schedulipg on

New Other Sprink]er a Non-Water-

Sensitive Crop Acres

Cost per kWh Saved

$\begin{array}{llllllllllll}\text { Year } & 0 & 5 & 10 & 15 & 20 & 25 & 30 & 35 & 40 & 45 & -50 \\ 1985 & 0.00 & 0.00 & 0.00 & 0.00 & 0.00 & 0.00 & 0.02 & 0.02 & 0.09 & 0.09 & 0.12 \\ 1986 & 0.00 & 0.00 & 0.00 & 0.00 & 0.00 & 0.00 & 0.03 & 0.03 & 0.16 & 0.16 & 0.21 \\ 1987 & 0.00 & 0.00 & 0.00 & 0.00 & 0.00 & 0.00 & 0.04 & 0.05 & 0.24 & 0.24 & 0.31 \\ 1988 & 0.00 & 0.00 & 0.00 & 0.00 & 0.00 & 0.00 & 0.05 & 0.06 & 0.32 & 0.32 & 0.40 \\ 1989 & 0.00 & 0.00 & 0.00 & 0.00 & 0.00 & 0.00 & 0.07 & 0.08 & 0.39 & 0.39 & 0.50 \\ 1990 & 0.00 & 0.00 & 0.00 & 0.00 & 0.00 & 0.00 & 0.08 & 0.10 & 0.42 & 0.42 & 0.54 \\ 1991 & 0.00 & 0.00 & 0.00 & 0.00 & 0.00 & 0.00 & 0.09 & 0.12 & 0.46 & 0.46 & 0.59 \\ 1992 & 0.00 & 0.00 & 0.00 & 0.00 & 0.00 & 0.00 & 0.09 & 0.12 & 0.47 & 0.47 & 0.60 \\ 1993 & 0.00 & 0.00 & 0.00 & 0.00 & 0.00 & 0.00 & 0.09 & 0.13 & 0.50 & 0.50 & 0.64 \\ 1994 & 0.00 & 0.00 & 0.00 & 0.00 & 0.00 & 0.00 & 0.09 & 0.14 & 0.53 & 0.53 & 0.67 \\ 1995 & 0.00 & 0.00 & 0.00 & 0.00 & 0.00 & 0.00 & 0.10 & 0.15 & 0.56 & 0.57 & 0.71 \\ 1996 & 0.00 & 0.00 & 0.00 & 0.00 & 0.00 & 0.00 & 0.10 & 0.16 & 0.60 & 0.61 & 0.76 \\ 1997 & 0.00 & 0.00 & 0.00 & 0.00 & 0.00 & 0.00 & 0.10 & 0.17 & 0.63 & 0.63 & 0.78 \\ 1998 & 0.00 & 0.00 & 0.00 & 0.00 & 0.00 & 0.00 & 0.11 & 0.17 & 0.64 & 0.64 & 0.80 \\ 1999 & 0.00 & 0.00 & 0.00 & 0.00 & 0.00 & 0.00 & 0.11 & 0.19 & 0.69 & 0.70 & 0.87 \\ 2000 & 0.00 & 0.00 & 0.00 & 0.00 & 0.00 & 0.00 & 0.11 & 0.20 & 0.75 & 0.76 & 0.94 \\ 2001 & 0.00 & 0.00 & 0.00 & 0.00 & 0.00 & 0.00 & 0.11 & 0.22 & 0.79 & 0.79 & 0.97 \\ 2002 & 0.00 & 0.00 & 0.00 & 0.00 & 0.00 & 0.00 & 0.11 & 0.22 & 0.80 & 0.80 & 0.99 \\ 2003 & 0.00 & 0.00 & 0.00 & 0.00 & 0.00 & 0.00 & 0.12 & 0.23 & 0.83 & 0.84 & 1.03\end{array}$

(a) Other sprinkler irrigation systems are handmove, sideroll, and solidset systems.

(b) For purposes of this study, non-water-sensitive crops are defined as wheat, hay, orchard and other miscellaneous crops.

It should be emphasized that all of the estimates presented in this chapter are based solely upon the direct energy savings of irrigation scheduling. The indirect energy savings that could accrue from reducing water withdrawals from the regions' hydroelectric systems have not been incorporated in this analysis. Thus, the total energy savings that could occur from improved irrigation scheduling reported here may be significantly understated and the costs per $\mathrm{kWh}$ saved may be overstated. In addition, the benefits of 
the increased crop yields that have been reported for improved scheduling were not considered in the study.

It should aiso be recognized that the potential water and energy savings from the use of improved scheduling have not been extensively demonstrated through field testing in the Pacific Northwest, particularly on other sprinkler acres. Conservative estimates of these savings were used in this study. The possibility exists that further research will demonstrate that improved scheduling is more cost effective and has higher potential energy savings than the results presented in this chapter indicate. 
$-$

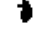

$\checkmark$

• 


\section{REFERENCES}

Biere, Arlo W., E.T. Kanemasu and E. Stanley Lee. 1981. Modeling Crop Response for Economic Water Use and for Water Conservation. NTIS BP82108473, Kansas Water Resources Research Institute, Kansas State University, Manhattan, Kansas.

Buchheim, Jerry F., and Lowell F. Ploss. 1977. "Computerized Irrigation Scheduling Using Neutron Probes." Paper No. 77-2004, presented at the American Society of Agricultural Engineers Annual Meeting, June 26-29, 1977, St. Joseph, Michigan.

Considine, Douglas M., ed. 1983. Van Nostrand's Scientific Encyclopedia. 6th Edition. Van Nostrand Reinhoid Company, New York.

Crop Care Associates. 1983. A Comprehensive Guide to Irrigation Scheduling. Crop Care Associates, Fresno, Californía.

Davenport, D. C., et al. 1981. Incidental Effects of Agricultural Water Conservation. Technical Completion Report (DWR Agt. No. B-534/2) to California State Department of Water Resources. Department of Land, Air and Water Resources, University of California, Davis, California.

Fischbach, Paul E. 1980a. Irrigation Management - A Mechanism for Saving Energy and Water. NTIS PB80-190614, Nebraska University, Dept. of Agricultural Engineering, Lincoln, Nebraska.

Fischbach, Paul E. 1980b. Improved Water and Fertility Management for Irrigation Systems - Phase 2. NTIS PB80-193832, Nebraska University, Dept. of Agricultural Engineering, Lincoln, Nebraska.

Fischbach, P. E. and C. A. Hoover. Tensiometer Agriculture. Agricultural Engineering Department, University of Nebraska, Lincoln, Nebraska.

Green, A. 19B2. In Texas, Computerized Irrigation Management Does Reduce Cost. Texas Farmlands, Inc.

Jensen, Marvin E. 1975. Scientific Irrigation Scheduling for Salinity Control of Irrigation Return Flows. NTIS PB-249114, USDA-ARS-Western Region, Snake River Conservation Research Center, Kimberly, Idaho.

Jensen, Marvin E. 1978. "Status of Irrigation Scheduling Technology and Its Application in the U.S.A." Paper presented at the American Agricultural Economics Association Symposium on Crop Response to Irrigation, August 7-9, 1978, Blacksburg, Virginia.

Larson, J. A. 1981. An Economic Analysis of Alternative Irrigation Scheduling Methods. Dissertation, University of Nebraska, Lincoln, University Microfilms International, Ann Arbor, Michigan. 
Locke, K. A. 1983. "How to Irrigate the Crops We Grow." USDA Cooperative Extension Service, Minidoka County, Rupert, Idaho.

Lord, J.M., Jr., and J.L. Gartang. 1981. The Effect of Irrigation Scheduling on Energy Consumption. U.M. Lord Incorporated, Fresno, California.

Merchant, J. P. and P. M. Herman. 1984. Marketing Study of Irrigation Scheduling Services. David M. Dornbusch and Company, San Francisco, California. Prepared for the Bonneville Power Administration.

Rosenberg, Norman J., et a1. 1983. Demonstration and Evaluation of the Use of Climate Information to Support Irrigation Scheduling and other Agricultural Operations. CAMAC Progress Report 83-1, University of Nebraska, Center for Agricultural Meteorology and Climatology, Institute of Agriculture and Natural Resources, Lincoln, Nebraska.

Sprinkler Irrigation Association. 1975. Sprinkler Irrigation. 4th Edition. C.H. Pair, ed. Sprinkler Irrigation Association, Silver Springs, Maryland.

U.S. Bureau of Reclamation. 1983. Energy and Water Conservation Opportunities: Lake Chelan Reclamation District. U.S. Bureau of Reclamation, Boise, Idaho.

U.S. Department of Agriculture (USDA). 1978. Water Conservation and Salvage Report for Montana. Soil Conservation Service, River Basin and Watershed Planning Staff, Bozeman, Montana.

Wilton, Neil D. 1983. 1982 Field Trial and Irrigation Water Management Study. USDA Soil Conservation Service et al., Bingham, FrankTin, Gem, and payette counties, Idaho. 
PNL -5416

UC $-95 \mathrm{C}$

\section{DISTRIBUTION}

No. of

Copies

OFFSITE

2 Fred Gordon

Bonneville Power Administration

P.0. Box 3621

Portland, OR 97208

30 DOE Technical Information Center

Mary Corrigan

Department of Energy

Forrestal Building

Washington, D.C. 20585

ONSITE

DOE Richland Operations Office

H. E. Ransom

14 Pacific Northwest Laboratory

R. C. Adams

A. J. Lezberg

G. L. Wilfert

B. J. Harrer (4)

Publishing Coordination (2)

Technical Information (5) 


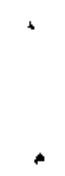

' 